\title{
LA ESCUELA ISLAMISTA DE LA ECONOMÍA POLÍTICA DEL DESARROLLO
}

\author{
Antonio Luis Hidalgo-Capitán ${ }^{1}$ \\ Universidad de Huelva
}

\begin{abstract}
Resumen:
En este artículo estudiamos el pensamiento islamista sobre desarrollo por medio de la construcción retrospectiva de la escuela islamista de la Economía Política del Desarrollo.

Hemos tratado de responder a la pregunta de si existe una escuela islamista del desarrollo, y para ello hemos estudiado el origen y la evolución del pensamiento islamista sobre desarrollo, hasta identificar a los principales centros de producción del pensamiento islamista sobre desarrollo, los principales autores, la vinculación entre ellos y sus principales obras. Posteriormente, hemos tratado de extraer de dichos textos una concepción islamista del desarrollo y hemos elaborado una síntesis compilatoria de los principales tópicos que se localizan en aquellos documentos (la reacción frente al colonialismo y neocolonialismo y las bases económicas y políticas del desarrollo de los países islámicos).

Llegamos a la conclusión de que existe una escuela islamista del desarrollo que estaría formada por aquellos autores que se han acercado al estudio del desarrollo y el subdesarrollo de los países musulmanes, partiendo de la premisa de que el Islam no es sólo una religión sino también es una forma de organización económica, social y política del Estado derivada del Corán, y que, por tanto, rechazan la separación entre la religión y el Estado.
\end{abstract}

Palabras clave: Economía Política; desarrollo; subdesarrollo; islamismo; sistema económico islámico; Economía Islámica.

\section{Abstract:}

In this article we study the Islamist thought on development by means of the retrospective construction of the Islamist school of Political Economy of Development. Our purpose is answering this question: Does an Islamist school of the development exist? To do it, we have studied the origin and the evolution of the Islamist thought on development, up to identifying to the key Islamist centres of production of thought on development, the key authors, the relationships between them and theirs most principal papers. Later, we have tried to extract an Islamist conception of the development from the above mentioned texts and we have elaborated a synthesis of the principal topics located in those documents -the reaction to the colonialism and neo-colonialism; the economic and political foundations of the development of the Islamic countries-. After this, we concluded that an Islamist school of the development does exist. This school is integrated by those authors who have focused the study of the development and the underdevelopment of the Moslem countries considering that Islam is not only a religion but rather a way of economic, social and political organization of the State, derived from the Koran, rejecting therefore the separation between religion and State.

Keywords: Political Economy; development; underdevelopment; Islamism; Islamic economic system; Islamic Economics.

Copyright (C) UNISCI, 2011.

Las opiniones expresadas en estos artículos son propias de sus autores, y no reflejan necesariamente la opinión de UNISCI. The views expressed in these articles are those of the authors, and do not necessarily reflect the views of UNISCI.

\footnotetext{
${ }^{1}$ Antonio Luis Hidalgo-Capitán es experto en temas de Economía Política Internacional y del Desarrollo. Es Profesor Titular de Economía Aplicada en la Universidad de Huelva. Ha sido Experto Internacional Invitado del Sistema Económico Latinoamericano, Investigador Visitante en la De Montfort University del Reino Unido y Profesor Invitado en las Universidades de Costa Rica, Centroamericana (Nicaragua), Andina Simón Bolívar (Ecuador), Tecnológica de Santiago (República Dominicana), de Guadalajara (México) y de La Habana (Cuba).E-mail: alhc@uhu.es.
} 


\section{Introducción}

La Economía Política del Desarrollo es aquella rama de la Economía Política Global o Nueva Economía Política Internacional dedicada al estudio del tópico del desarrollo. Al ser la Economía Política Global una especialidad académica multidisciplinar de la que participan, principalmente politólogos (especializados en Relaciones Internacionales) y economistas (especializados en Economía Internacional), pero también juristas, antropólogos, geógrafos, sociólogos y otros intelectuales, sus trabajos suelen atender a la multidimensionalidad de los fenómenos objeto de estudio ${ }^{2}$; así, los trabajos de Economía Política Global centrados en el estudio del desarrollo, es decir, los trabajos de Economía Política del Desarrollo analizan dicho fenómeno como algo más que un mero fenómeno económico (desarrollo económico), es decir, como un fenómeno multidimensional que requiere de la utilización de variables económicas, pero también políticas, y sociales, y culturales, y geográficas... ${ }^{3}$

A partir de este enfoque, nuestro objeto de estudio será la reconstrucción histórica del pensamiento sobre desarrollo, tomando como referencia de análisis la actual Economía Política del Desarrollo, es decir, aplicaremos la retrospección (perspectiva absolutista de Blaug $^{4}$ ). Pero, como ya hicieran Hunt e Hidalgo-Capitán para la Economía del Desarrollo ${ }^{5}$, utilizaremos también el enfoque de los paradigmas competitivos de Khun $^{6}$ (perspectiva relativista de Blaug ${ }^{7}$ ), al entender que el pensamiento sobre desarrollo evoluciona dentro de comunidades epistemológicas bajo las cuales se determina la validez de sus estudios. A dichas comunidades respecto del desarrollo, formadas por economistas, politólogos, juristas, sociólogos, geógrafos y antropólogos, fundamentalmente, las denominamos escuelas del desarrollo, o en retrospección, escuelas de la Economía Política del Desarrollo. Dicho de otro modo, las escuelas de la Economía Política del Desarrollo que vamos a identificar son una reconstrucción retrospectiva (perspectiva absolutista), pero la validez de sus estudios debe ser determinada en el contexto de cada comunidad epistemológica (perspectiva relativista).

En un reciente trabajo, Hidalgo-Capitán identifica siete escuelas de pensamiento sobre desarrollo, la de la modernización, la estructuralista, la neomarxista, la neoliberal, la alternativa, la neoinstitucionalista y la islamista ${ }^{8}$.

\footnotetext{
${ }^{2}$ Véanse, por ejemplo, Martínez González-Tablas, Ángel (2000): Economía Política de la Globalización, Barcelona, Ariel; Woods, Ngaire (2001): "International Political Economy in an age or globalization”, en Baylis, John y Smith, Steve (2003): The Globalization of World Politics, Nueva Cork, Oxford University Press, pp. 27798; o Bustelo, Pablo: "Enfoque de la Regulación y Economía Política Internacional. ¿Paradigmas convergentes?", Revista de Economía Mundial, no 8, (2003), pp. 143-173.

${ }^{3}$ La Economía Política del Desarrollo ha sido definida y analizada en profundidad en un reciente artículo publicado por la Revista de Economía Mundial (Hidalgo-Capitán, Antonio Luis (2011): "Economía Política del Desarrollo. La construcción retrospectiva de una especialidad académica", Revista de Economía Mundial, n 29); otros autores que utilizan dicho enfoque serían, por ejemplo: Bates, Robert H. (2001): Prosperity and Violence. The Political Economy of Development, Nueva York, Norton; Nef, Jorge (1995): Human Security and Mutual Vulnerability. The Global Political Economy of Development and Underdevelopment, Ottawa, International Development Research Centre; u Oya, Carlos y Santamaría, Antonio (eds.) (2007): Economía Política del Desarrollo en África, Madrid, Akal.

${ }^{4}$ Blaug, Mark (1962): Teoría económica en retrospección, ed. 1985, México, Fondo de Cultura Económica.

5 Hunt, Diana (1989): Economic Theory of Development. An Analysis of Competing Paradigms, Londres, Harvester Wheatsheaf; e Hidalgo-Capitán, Antonio Luis (1998): El pensamiento económico sobre desarrollo. De los mercantilistas al PNUD, Huelva, Servicio de Publicaciones de la Universidad de Huelva.

${ }^{6}$ Khun, Thomas (1962): La estructura de las revoluciones cientificas, ed. 2005, Madrid, Fondo de Cultura Económica.

${ }^{7}$ Blaug, op.cit.

${ }^{8}$ Hidalgo-Capitán, “Economía Política del Desarrollo..., op. cit.
} 
Pero ¿existe una escuela islamista del desarrollo?; es decir, ¿existe una concepción islamista, más o menos común, del desarrollo, diferente a las de otras escuelas? De ser así, ¿quiénes forman parte de dicha comunidad epistemológica?, ¿cuáles son los vínculos de influencia entre los miembros de dicha comunidad? ¿cuáles son las principales formas de hacer público su pensamiento? y ¿cuáles son los principales tópicos de dicha escuela?

En este artículo vamos a tratar de construir retrospectivamente una escuela islamista de la Economía Política del Desarrollo por medio de la identificación de la citada concepción común del desarrollo (aplicando el esquema de Griffin ${ }^{9}$ ), de sus principales pensadores (juristas, teólogos, educadores, economistas...), de sus principales documentos (textos académicos, textos biográficos, ensayos, discursos, epístolas, proclamas...) y de los tópicos más importantes que se recogen en ellos (desarrollo y subdesarrollo, bases económicas del desarrollo y bases políticas del desarrollo).

Para ello comenzaremos por estudiar el origen y la evolución del pensamiento islamista sobre desarrollo, aplicando técnicas de referencias cruzadas y bibliografía recursiva, hasta identificar a los principales centros de producción del pensamiento islamistas sobre desarrollo, los principales autores y la vinculación entre ellos, y, a partir de las páginas Web de los aquellos y de búsquedas en la red sobre éstos, localizar sus principales obras ${ }^{10}$. Posteriormente, trataremos de extraer de dichos textos, fundamentalmente de la bibliografía activa, pero también de la pasiva, una concepción islamista del desarrollo y realizaremos una síntesis compilatoria de los principales tópicos que se localizan en aquellos documentos.

La principal limitación con la que nos encontramos, y ello evidentemente introduce un sesgo en la investigación, es que gran parte de los autores islamistas escriben en árabe, urdu o persa $^{11}$ y los académicos occidentales dependemos de la existencia de traducciones a nuestras lenguas para tomarlas en consideración ${ }^{12}$.

No obstante, antes de continuar debemos aclarar la utilización del término "islamista", en lugar de "islámica", para referirnos a esta escuela. Nosotros entendemos por "islamismo" aquella ideología que sostiene que el Islam no es sólo una religión sino que también es una forma de organización económica, social y política del Estado derivada del Corán, y que, por tanto, rechaza la separación entre la religión y el Estado ${ }^{13}$.

\footnotetext{
${ }^{9}$ Griffin, Keith (1989): "Pensamiento sobre el desarrollo. La visión más amplia”, Desarrollo, n 15, pp. 3-5.

${ }^{10}$ A diferencias de otras escuelas de pensamiento "occidentales", los textos islamistas no se producen sólo en universidades y centros de investigación públicos y privados, sino también en escuelas coránicas, en cárceles (donde han cumplido prisión algunos intelectuales islamistas) y en la clandestinidad (cuando los intelectuales islamistas, en particular yihadistas, si sitúan al margen de la legalidad vigente); por este motivo sus textos y sus vías de comunicación tienen una naturaleza tan diversa.

${ }^{11}$ Las palabras y los nombres propios procedentes del árabe, el urdu o el persa se escriben de manera diferente según la lengua a la que se traducen; en este caso, hemos seguido los criterios de castellanización del Libro de Estilo de El País, en http://estudiantes.elpais.es/libroestilo/indice_estilos.htm (1977), a excepción de la bibliografía final en el que los nombres propios de los autores de textos en inglés o francés no aparecen castellanizados.

${ }^{12}$ Pryor, Frederic L. (1985): “The Islamic Economic System”, Journal of Comparative Economics, no 9, pp. 197223.

${ }^{13}$ En principio, se puede ser "islámico" o "musulmán” aceptando la separación entre la religión y el Estado, y de hecho muchos "musulmanes" así lo hacen. Sin embargo, los "islamistas", que suelen rechazar para sí mismos esta denominación y prefieren denominarse "musulmanes", no conciben que se pueda ser "musulmán" sin rechazar la separación entre la religión y el Estado. Ello supone que la expresión "islámico" en el discurso de un "islamista" pueda ser entendida, en la mayoría de los casos, como sinónimo de la expresión "islamista"; sería, por ejemplo, el caso de la "Economía Islámica", cuya expresión vamos a respetar en este trabajo, aunque consideramos que su denominación más adecuada debiera ser la de "Economía Política Islamista".
} 
En una primera aproximación pueden diferenciarse dos variantes del islamismo, coincidente con las dos principales ramas del Islam, el sunísmo y el chiísmo. Los islamistas suníes rechazan la manera en que los musulmanes suníes han vivido el Islam con posterioridad a la muerte de cuarto califa, Alí, (momento en que se produce la escisión de los chiíes) y proponen un retorno a la vivencia del Islam que existía en los tiempos del Profeta Mahoma y los cuatro primeros califas; además defienden el esfuerzo de interpretación individual del Corán, desplazando con ello a los ulemas como interpretes del Islam. En el caso de los islamistas chiíes, al pertenecer a la escuela imaní, consideran que el período de esplendor del Islam se corresponde con los tiempos en que gobernó el Profeta Mahoma y de su yerno Alí; y aunque valoran el esfuerzo de interpretación individual del Corán, siguen considerando muy importante el papel de los mulas y los ayatolás para interpretar los mensajes ocultos del Corán.

El islamismo, como ideología, se encuentra hoy día muy extendido por los ámbitos académicos del mundo musulmán, de ahí la expansión que ha experimentado la escuela islamista del desarrollo, desde los años cuarenta del siglo XX, a medida que dicha ideología se ha ido combinando con las explicaciones del subdesarrollo y las propuestas de estrategias de desarrollo. No obstante, en los últimos años dicha ideología se ha extendido también en los ámbitos urbanos, en particular en aquellas zonas más desfavorecidas.

\section{Origen y evolución de la Escuela Islamista del Desarrollo}

Aunque los economistas islamistas del desarrollo, propiamente dichos, no aparecieron en las universidades de los países musulmanes y de los países receptores de inmigrantes musulmanes (Reino Unido y Estados Unidos) hasta finales de los años setenta del siglo XX, no podría entenderse su surgimiento sin prestar atención a la evolución histórica del islamismo desde la Edad Media hasta la aparición de la primera generación de islamistas contemporáneos durante la primera mitad del siglo XX.

Dicha primera generación de islamistas estaría formada por el iraní Ruhola Musavi al Jomeini [1902-1989], el indio-pakistaní Abdul Ala Maududi [1903-1979], el argelino Malek Bennabi [1905-1973] y los egipcios Hasán al Banna [1906-1949] y Sayid Qutb [1906-1966]. Los planteamientos políticos de dichos islamistas proceden de al menos tres tradiciones diferentes: la escuela imaní o duodecimana de la rama chií (a la que pertenecía Jomeini); el deobandismo reformador de la escuela hanafí de la rama suní (al que pertenecía Maududi); y el salafismo reformador suní de influencia wahabista (al que pertenecían Al Banna, Qutb y Bennabi).

En el caso del salafismo, sus planteamientos son herederos de una larga tradición de pensamiento político islamista, que comenzaría con el turco Taqi al Din Ibn Taymiya [12631368] (que se reveló contra los mongoles a los que acusó de falta de fe islámica); pero alcanzaría su fase más productiva de la mano de los reformadores de los siglos XVIII y XIX $^{14}$ : el saudí Muhamad Abd al Wahab [1703-1792]; el yemení Muhamad al Shawkani [1760-1834]; el afgano Yamal al Din al Afgani [1838-1897]; el egipcio Muhamad Abduh [1849-1905]; el sirio Rashid Rida [1865-1935]; y el libanés Ahmad Rida [1872-1953]. El

\footnotetext{
${ }^{14}$ Los reformadores suníes se enfrentaron en su época con los liberales suníes, de los que derivarían los planteamientos políticos del nacionalismo árabe (e incluso del socialismo árabe) imperante en la mayoría de los actuales gobiernos de los países musulmanes.
} 
salafismo tenía a mediados del siglo XX una gran presencia en Egipto y, en su variante wahabí, en la Península Arábiga.

En el caso de deobandismo, sus planteamientos proceden de la escisión reformista de la escuela hanafí del sunismo impulsada por los indios Muhamad Qasim Nanautavi [18331877] y Rashid Ahmad Gangohi [1829-1905]. El deobandismo tenía a mediados del siglo XX una gran presencia en el subcontinente indio.

En el caso del imanismo, sus planteamientos constituyen la ortodoxia del chí́smo, la primera escisión del Islam producida en el año 661, y en concreto se basan en la escuela imaní o duodecimana que sigue las enseñanzas de los doce imanes chí́es. No obstante, el islamismo imanista, por lo que a la vía revolucionaria de implantación del Estado islámico se refiere, tendría importantes influencias del iraní Alí Shariati [1933-1977], contemporáneo de Jomeini. El imanísmo tenía una gran presencia a mediados del siglo XX en Irán, Irak y Líbano.

La primera gran organización político-religiosa islamista fue la Hermandad Musulmana (más conocida como los Hermanos Musulmanes), creada en Egipto (bajo protectorado británico) en 1928 por Hasán al Banna. El pensamiento político de este islamista salafista, cuyo proyecto era relativamente vago y sin mayores referencias a las cuestiones del desarrollo, estuvo influido por Rashid Rida, Abduh, Al Afgani y Wahab. Su obra más conocida sólo se encuentra en árabe y se trata de Mensajes del Imán Hasán al Banna, una colección de cartas y mensajes de dicho autor de diferentes fechas; aunque también existen otros documentos en árabe publicados en forma de casetes.

Sin embargo, el gran líder intelectual de los Hermanos Musulmanes fue el Sayid Qutb, cuyo pensamiento político vendría influido por Taymiya, Al Banna y Maududi ${ }^{15}$, y que, tras la muerte de este último en 1949, se incorporaría a la organización; este hecho coincidió con la publicación de su obra La justicia social en el Islam, texto en el que se recogía uno de los primeros análisis del subdesarrollo del mundo musulmán tras la descolonización y una estrategia de desarrollo. No obstante, el pensamiento político de Qutb se radicalizaría a lo largo del tiempo, en parte por la tortura a la que fue sometido en prisión, hasta llegar a la publicación su última obra Hitos del camino en 1966, que fue redactada en la cárcel y que se convertiría en el texto de referencia del yihadismo (islamismo radical y violento); en dicha obra acusa a las sociedades musulmanas de apostasía por haber abrazado el paganismo y exige la aplicación de la ley islámica por parte de los gobernantes de los países musulmanes.

Por otro lado, en la Argelia colonizada por Francia surgió la reacción contra la colonización por parte de intelectuales como Malek Bennabi, cuyo pensamiento venía influido por Abduh y Ahmad Rida. En sus obras Las condiciones del renacimiento. Los problemas de una civilización, de 1947, y la Vocación del Islam, de 1954, Bennabi responsabilizaba del subdesarrollo a la colonización de los países musulmanes por parte de potencias occidentales y a sus efectos en dichas sociedades tras la descolonización. Otra obra donde se sintetiza el pensamiento de este autor es su autobiografía Memorias de un testigo del siglo, publicada en 1965. A diferencia de Qutb, Bennabi fue un islamista moderado.

Una segunda organización islamista fue el Partido Islámico o Yamaat e Islami, fundado por Abdul Ala Maududi en 1941 en la India. Su pensamiento político venía influido por

\footnotetext{
${ }^{15}$ La influencia de Maududi en Qutb ha sido constatada por varios autores; véase Kepel, Gilles (1985): The Prophet and Pharaoh: Muslim Extremism in Egyp, Londres, Al Saqi, p. 48.
} 
Taymiya, Nanautavi, Gangohi y Al Banna ${ }^{16}$. Maududi publicó en 1939 su obra La Yihad en el Islam, en la que defiende la vía violenta para la implantación universal del estado islámico; ese mismo año publica Teoría política del Islam, que luego ampliaría en 1955 en su libro La Ley islámica y la Constitución, en los cuales plantea las bases del Estado islámico conformado como califato; posteriormente, en 1941, publica El problema económico del hombre y su solución islámica, obra en la que hace una crítica al capitalismo y al socialismo como sistemas económicos proponiendo la instauración de un sistema económico islámico.

Hacia mediados del siglo XX ya se había producido una cierta confluencia $\mathrm{y}$ contaminación mutua entre el salafismo wahabista del gobierno de Arabia Saudí, el salafismo de los Hermanos Musulmanes de Egipto y el deobandismo del Partido Islámico de Pakistán, de forma que un pensamiento político islamista más o menos homogéneo se fue extendiendo por todo el Islam suní durante la segunda mitad de dicho siglo ${ }^{17}$.

En el Islam chií, el imanismo seguía siendo la escuela principal a mediados del siglo XX bajo el liderazgo de Ruhola Musavi al Jomeini, que se convertiría a la postre en el líder de la Revolución Islámica Iraní, que trajo consigo la implantación de un Estado islámico en 1979. La obra más conocida de Jomeini es El gobierno islámico, elaborada en su exilio en la Hawza de Nayaf (Irak $)^{18}$ y publicada en 1970, en la que plantea las reformas que son necesarias para establecer un Estado islámico en los países musulmanes; no obstante, la mayor parte de sus mensajes se han publicado en persa, muchos de ellos en forma de casetes. Otro destacado islamista chií sería el iraní Morteza Motahari [1920-1979], discípulo de Jomeini.

Varias son las causas que explicarían el surgimiento de la escuela islamista de la Economía Política del Desarrollo durante los años cuarenta ${ }^{19}$. En primer lugar, la existencia de un pensamiento islamista previo, heredado de los reformadores sunís de los siglos XVIII y XIX, articulado en torno al salafismo, al wahabismo y al deobandismo, y enfrentado al liberalismo suní. En segundo lugar; la toma de conciencia por parte de los intelectuales de los países islámicos del nivel de atraso económico relativo de sus naciones, fruto de la colonización por parte de potencias occidentales no islámicas. En tercer lugar, la aparición de movimientos de liberación nacional en los países islámicos colonizados y neocolonizados (protectorados, presencia de ejércitos extranjeros...) durante el segundo cuarto del siglo XX, que cuestionaban las bondades de la influencia occidental sobre el desarrollo de los mismos. $\mathrm{Y}$ en cuarto lugar, la reacción frente al autoritarismo del nacionalismo árabe, representado por los gobiernos de los países islámicos tras su independencia y que se consideraba heredero de la tradición del pensamiento liberal suní del siglo XIX.

El surgimiento de una concepción islamista del desarrollo, puesta de manifiesto por los cinco autores citados, se basó así en el rechazo del capitalismo occidental, como sistema económico por medio del cual alcanzar el desarrollo, y en responsabilizar del subdesarrollo de dichos países a la expansión de dicho sistema sobre el mundo musulmán. De esta forma, los trabajos pioneros de Maududi, Qutb y Bennabi, elaborados durante los años cuarenta del siglo $\mathrm{XX}$, se convirtieron en la base de la concepción islamista del desarrollo que, a finales de los

\footnotetext{
${ }^{16}$ La influencia de Al Banna en Maududi, pese a pertenecer a corrientes islamistas diferentes, ha sido sostenida por algunos autores; véase Rashid, Ahmed (2000): Taliban. Militant Islam, Oil and Fundamentalism in Central Asia, New Haven, CT, Yale University Press, p. 89.

${ }^{17}$ Al Banna influyó en Maududi, Maududi y Al Banna en Qutb y Qutb en el wahabismo saudí.

${ }^{18}$ Las hawzas son seminarios de estudios islámicos chíes equivalentes a las escuelas coránicas o madrazas suníes.

${ }^{19}$ Al Banna sería un precursor, mientras que Jomeini sería un "fundador” tardío de la rama chií.
} 
años setenta, se popularizó en los círculos académicos de los países musulmanes y entre los académicos musulmanes residentes en países occidentales.

La segunda generación de islamistas, entre los que se encontrarían los primeros economistas islamistas, es decir, los fundadores de la "Economía Islámica"20, comenzó a realizar sus primeras aportaciones durante los años setenta y ochenta del siglo XX, desde una serie de centros de investigación y de producción intelectual del pensamiento islamista como fueron: la Fundación Islámica de Leicester (Reino Unido), creada en 1973; la Oficina de Investigación de la Economía Islámica de Dhaka (Bangladesh), creada en 1976; el Centro de Investigación de la Economía Islámica de la Universidad Rey Abdulaziz de Yidda (Arabia Saudí), creado en 1977; el Instituto Internacional de Pensamiento Islámico de Herndon (Estados Unidos), creado en 1981; el Instituto de Investigación y Formación Islámica del Banco Islámico de Desarrollo de Yidda (Arabia Saudí), creado en 1981; la Organización Cultural, Científica y Educativa Islámica de la Organización de la Conferencia Islámica de Rabat (Marruecos), creada en 1982; el Instituto Internacional de Economía Islámica de la Universidad Islámica Internacional de Islamabad (Pakistán), creado en 1983; y el Colegio de Economía de la Universidad Internacional Islámica de Kuala Lumpur (Malasia), creado en 1983. Además destaca el papel desempeñado por dos importantes asociaciones: la Asociación de Científicos Sociales Musulmanes (Estados Unidos), creada en 1972, y la Asociación Internacional de Economía Islámica, creada en $1984^{21}$.

De todas ellas, las tres instituciones que más han contribuido a la difusión en inglés de la Economía Islámica tal vez sean: la Fundación Islámica (editora desde 1991 de la Revista de Economía Islámica); el Centro de Investigación de la Economía Islámica (editor desde 1989 de la Revista de la Universidad Rey Abdulaziz: Economía Islámica) ${ }^{22}$; y el Instituto de Investigación y Formación Islámica (editor desde 1993 de la revista Estudios de Economía Islámica).

Entre los primeros economistas islamistas suníes cabría destacar: al indio Muhamad Nejatullah Siddiqi [1931-]; al indio-pakistaní Khurshid Ahmad [1932-]; al pakistaní-saudí Muhamad Umer Chapra [1933-]; al bengalí Muhamad Abdul Mannan [1938-]; al sirioestadounidense Monzer Kahf [1940-]; al pakistaní Muhamad Akram Khan [1945-]; y al egipcio Abdel Hamid El Ghazali [1937-]. Es muy significativo que cinco de estos autores procedan del subcontinente indio, donde predomina el islamismo deobandista y donde la figura de Maududi está considerada como el primer economista islamista, pese a no haber cursado ninguna titulación universitaria de Economía; de hecho Ahmad, fundador de la Fundación Islámica, fue discípulo de Maududi y casi todos ellos han estado vinculados con la Fundación Islámica, el Centro de Investigación de la Economía Islámica o el Instituto de Investigación y Formación Islámica. No obstante, los trabajos de estos economistas islamistas proceden de una larga tradición de pensamiento económico islámico cuyo principal exponente fue sin duda el pensador tunecino Abderramán Ibn Jaldún [1332-1406], autor de Prolegómenos. Introducción a la Historia Universal, publicada en 1382.

\footnotetext{
${ }^{20}$ La Economía Islámica tiene dos grandes campos de estudio; por un lado, el sistema económico islámico, y por otro lado, la banca y las finanzas islámicas. Mientras el primero está directamente relacionado con el desarrollo económico y es objeto de estudio en este trabajo, el segundo, por tratarse de un tema específico, no ha sido considerado aquí.

${ }^{21}$ Chapra, Muhammad Umer (1996): What is Islamic Economics? Yidda, Islamic Research and Training Institute (Islamic Development Bank), pp. 45-46.

${ }^{22}$ Entre 1983 y 1985 este centro publicó la Revista de Investigación en Economía Islámica.
} 
Algunos de estos autores han realizado un interesante trabajo de compilación y comentario de la bibliografía sobre economía desde una perspectiva islámica, destacando los trabajos de Siddiqi, Ahmad y Khan ${ }^{23}$.

Entre las publicaciones de Ahmad destacan el trabajo pionero Desarrollo económico en un marco islámico, de 1979, y el más reciente Los retos económicos contemporáneos y el Islam, de 2002. En el caso de Siddiqi, destaca también su trabajo pionero Un enfoque islámico del desarrollo económico, de 1977, así como otros trabajos más recientes tales como El papel del Estado en la economía, de 1996, y Economía. Un enfoque islámico, de 2001. Chapra, por su parte, en su obra El sistema económico islámico, publicado, en 1970, fue uno de los primeros en desarrollar dicho concepto, y posteriormente, en 1996, publicó un interesante survey titulado ¿Qué es la Economía Islámica?; aunque también destacan su libro Islam y desarrollo económico, de 1994, y la compilación El futuro de la Economía. Una perspectiva islámica, de 2000. Otro trabajo pionero es el de Kahf, que en 1978 publicó La Economía Islámica. Estudio analítico del funcionamiento del sistema económico islámico. Mientras que los trabajos más relevantes de Khan son El reto de la Economía Islámica, de 1985, y Un glosario de Economía Islámica, de 1990. De El Ghazali destaca un survey sobre el desarrollo desde la perspectiva islámica, titulado El hombre es la base de la estrategia islámica para el desarrollo económico, publicado en 1988.

Aunque la mayor parte del desarrollo de la Economía Islámica procede de la escuela suní, existe una variante chií, de la que el iraquí Muhamad Baqir al Sadr [1935-1980], líder de la Hawza de Nayaf influido por Jomeini ${ }^{24}$, es su principal exponente, siendo su obra más importante Nuestra Economía, publicada en 1961 y en la que se expone la visión chií de la Economía Islámica.

Varias son las causas que explican el nacimiento de la Economía Islámica, y por tanto, el afianzamiento de la escuela islamista de Economía Política del Desarrollo. En primer lugar, la formación de musulmanes inmigrantes, procedentes del subcontinente indio y de la tradición deobandista, en su mayoría, en las Facultades de Economía de las universidades británicas y estadounidenses. En segundo lugar, el exilio, en la península arábiga, de islamistas salafistas egipcios, en su mayoría vinculados con los Hermanos Musulmanes, durante los años sesenta que permitió una fusión intelectual entre salafismo y wahabismo. En tercer lugar, el aumento de los precios del petróleo durante las décadas de los setenta y ochenta, que enriqueció a la monarquía saudí y a otros gobiernos de los países del Golfo Pérsico, en su mayoría de tradición wahabista, y que propició la existencia de recursos para financiar por todo el mundo centros de investigación e investigadores afines a dicha corriente del islamismo, e incluso a otras. En cuarto lugar, la búsqueda de una tercera vía entre capitalismo y socialismo, entre la teoría de la modernización y la teoría de la dependencia, que permitiera articular una propuesta de desarrollo alternativa para los países islámicos en el

\footnotetext{
23 Siddiqi, Mohammed Nejatullah (1978): Contemporary Literature on Islamic Economics, Leicester, The Islamic Foundation; Siddiqi, Mohammed Nejatullah (1981): Muslim Economic Thinking. A Survey of Contemporary Literature, Leicester, The Islamic Foundation; Ahmad, Kurshid (ed.) (1980): Studies in Islamic Economics, Leicester, The Islamic Foundation; Khan, Muhammad Akram (1983): Issues in Islamic Economics, Lahore, Islamic Publications; Khan, Muhammad Akram (1984/1985): Islamic Economics: Annotated Sources in English and Urdu, Leicester, The Islamic Foundation; Khan, Muhammad Akram (1985): Challenge of Islamic Economics, Lahore, All-Pakistan Islamic Education Congress; y Khan, Muhammad Akram (1992): Economic System of Islam: Bibliography of studies in English published during 1940-1990; Yidda, Islamic Economics Research Centre.

${ }^{24}$ Jomeini pasó 14 años en la Hawza de Najaf tras su exilio, donde coincidió con Al Sadr; de hecho, la ejecución de éste por parte del gobierno iraquí se debió, entre otras cosas, a su apoyo a la Revolución Islámica Iraní liderada por aquél y a los vínculos que mantenía con él.
} 
contexto de los años setenta y ochenta. En quinto lugar, el triunfo de la Revolución Islámica en Irán y la implantación de la ley islámica en Pakistán en 1979, junto con el fortalecimiento de los gobiernos islámicos de las monarquías del Golfo Pérsico, que propiciaron un gran optimismo sobre la expansión del Estado islámico, a principios de los años ochenta, para lo que se necesitaba un sustento teórico. Y en sexto lugar, la creación de la Organización de la Conferencia Islámica en 1969 y del Banco Islámico de Desarrollo, en 1975, como instrumentos de cooperación y promoción del desarrollo de los países islámicos.

Sin embargo, durante la década de los noventa del siglo XX surgió una tercera generación de islamistas ${ }^{25}$, directamente vinculada con el yihadismo ${ }^{26}$. Algunos islamistas radicales suníes ${ }^{27}$, decepcionados por la imposibilidad de instaurar un Estado islámico en sus países (por no alcanzar el respaldo popular suficiente en las elecciones o por serles impedido el acceso al poder debido al autoritarismo de los gobiernos liberales), o decepcionados con la forma que adopta el Estado islámico en sus países, se plantean la toma del poder por la vía de guerra santa o yihad contra los "infieles" que detentan el poder. Surgen de esta forma grupos armados islamistas en diferentes países musulmanes (Egipto, Afganistán, Argelia, Marruecos, Pakistán, Filipinas, Sudeste Asiático, Rusia...), considerados terroristas por los gobiernos de los países occidentales.

Entre dichas organizaciones destacan, por ser las primeras, la Yihad Islámica y el Grupo Islámico o Al Gama al Islamiya, ambas creadas en Egipto durante los años setenta como escisiones de los Hermanos Musulmanes; sin embargo, su ejemplo fue seguido durante los años ochenta y noventa por decenas de organizaciones islamistas, hasta confluir, la mayoría de ellas, hacia finales de los noventa y principios del siglo XXI en la red terrorista Al Qaeda, liderada por el saudí Osama Bin Laden [1957-] y el egipcio Aimán al Zawahiri [1951].

Al Qaeda se creó en 1998 en Afganistán al agrupar a yihadistas salafistas (como Al Zawahiri $^{28}$ ), wahabistas (como Bin Laden ${ }^{29}$ ) y deobandistas (como los talibanes afganos, liderados por el mulá Muhamad Omar $\left.[1959-]^{30}\right)$. La aparición y expansión de esta organización ha supuesto la globalización de la yihad, por entender que los gobiernos "impíos

\footnotetext{
${ }^{25}$ Algunos autores se refieren a esta generación de islamistas radicales suníes como "neofundamentalistas", por entender que son una escisión del islamismo que comparte algunos postulados con los "fundamentalistas" o "tradicionalistas"; véase Roy, Oliver (2002): "Neofundamentalismo", en http://www.cholonautas.edu.pe/modulo/unload/neofund.pdf.

${ }^{26} \mathrm{Si}$ bien esta tercera generación de islamistas, al igual que la segunda, tienen en Qutb, Maududi y Jomeini sus principales referentes intelectuales, aquéllos se han preocupado más por desarrollar (y sobre todo aplicar) sus postulados políticos, mientras que los economistas islamistas lo hicieron con los postulados económicos. La mayoría de los economistas islamistas no comparten la vía violenta de toma del poder, ni el terrorismo islamista, aunque sí pueden compartir otros postulados referentes al Estado islámico y el califato.

${ }^{27}$ El islamismo moderado suní se fue "nacionalizando" durante los años noventa, centrando su preocupación en la lucha política nacional y abandonando su condición supranacional; aspecto éste que fue aprovechado por el islamismo yihadista para erigirse como un movimiento supranacional, cuyo principal exponente sería Al-Qaeda (véase Roy, op. cit.). No obstante, existen movimientos yihadistas de orientación nacional, como sería el caso de Hamás en Palestina.

${ }^{28}$ Al Zawahiri ya militaba en los Hermanos Musulmanes un año antes de la ejecución de Qutb y estuvo muy influido por su pensamiento, hasta el punto de rendirle homenaje en Al-Zawahiri, Ayman: "Knights under the Prophet's Banner", Al-Sharq al-Awsat, (2-10 December 2001), Londres.

29 Según algunos autores, Bin Laden fue discípulo del hermano de Sayid Qutb, Mohamed Qutb, en la Universidad King Abdelaziz, quien le transmitió las ideas básicas de su pensamiento (véase Kepel, Gilles (2002): Jihad: The Trial of Political Islam, Londres, Tauris, p. 314).

${ }^{30}$ Aunque los talibanes afganos no están directamente influidos por el Partido Islámico de Abdul Ala Maududi, sí que lo están por otro partido islamista deobandista pakistaní (véase, Rashid, op. cit., p. 29).
} 
y corruptos" que controlan la mayoría de los países islámicos (“el enemigo interno") no pueden ser derrotados porque cuentan con el apoyo económico, político y militar de los países occidentales ("el enemigo externo"); por tanto, la yihad ha de dirigirse también contra los países (gobiernos, ejércitos, intereses económicos...) que apoyan a los gobiernos "infieles" de los países musulmanes, hasta liberar a dichos países de su influencia y poder conformar un nuevo califato en los territorios de éstos ${ }^{31}$. En la estructura política de Al Qaeda, Bin Laden sería el Emir y Director de Operaciones, mientras que Al Zawahiri sería Subdirector de Operaciones; aunque la mayoría de los analistas coinciden en señalar a Al Zawahiri como el líder intelectual de la organización.

Los textos más destacados del islamismo yihadista serían: Declaración de guerra contra los americanos que ocupan la tierra de los lugares sagrados, más conocido como la Fatwa de Bin Laden, la Fatwa de 1996 o la Epistola Ladenesa, firmada por Bin Laden y publicada en 1996; Yihad contra judios y cruzados, más conocida como la Fatwa de Al Qaeda, la Fatwa de 1998 o la Declaración Fundacional del Frente Islámico Mundial, firmado por Bin Laden, Al Zawahiri y otros tres líderes yihadistas y publicado en 1998; Caballeros bajo el estandarte del Profeta, más conocido como El Manifiesto de Al Qaeda o la Autobiografia de Al Zawahiri, publicado en 2001; y Carta de Al Zawahiri a Al Zarqawi, publicada en 2005. En dichos documentos no sólo se hace una defensa de la yihad, sino que en algunos de ellos se defiende también la reinstauración del califato. No obstante, conviene señalar que la mayor parte de los mensajes de los islamistas yihadistas se hacen públicos en archivos de vídeos y de audio colgados en diferentes páginas webs y por medio de la cadena de televisión Al Jazeera.

La defensa del reestablecimiento del califato que hacen los yihadistas es compartida también por algunas organizaciones islamistas transnacionales, tales como los Hermanos Musulmanes y su escisión, el Partido de la Liberación o Hizb ut Tahrir. Dicha organización, fundada en 1953, se ha convertido en un partido islamista global que tiene como principal objetivo el establecimiento de un califato moderno (en principio por la vía pacífica, aunque algunos de sus miembros más radicalizados han abrazado abiertamente el yihadismo). No obstante, entre las aportaciones de los Hermanos Musulmanes que defienden la conformación de un califato islámico por la vía pacífica destaca la de Abdel Hamid El Ghazali, recogida en su obra El camino al renacimiento de la comunidad islámica de creyentes, publicada en 2001.

Dentro de la variante chii ${ }^{32}$, la implantación del Estado islámico en Irán trasladó la yihad hacia el Líbano, donde la organización islamista Partido de Alá o Hezbolá, liderada por Muhamad Husein Fadlallah [1935-] y fundada en 1979 como respuesta a la ocupación israelí del sur del país, participó como milicia en la guerra civil libanesa [1975-1990] y, más recientemente, en el conflicto israelo-libanés [2006]; así mismo, la invasión de Irak [2003-], por parte de la coalición internacional liderada por EEUU, hizo también que se desarrollará una milicia armada islamista chí́, liderada por el clérigo Múqtada al Sáder [1973-], denominada Ejército de El Mahdi y vinculada el partido Bloque Sáder. Por su parte, el actual Líder Supremo de Irán, Alí Huseini Jamenei [1939-], sucesor de Jomeini, en su mensaje El enemigo interno, el enemigo externo y la guerra psicológica, de 2007, sin llegar a proponer

\footnotetext{
${ }^{31}$ El yihadismo suní también se encuentra enfrentado con islamismo chií; esto es más evidente en la estrategia seguida por el jordano Abu Muzab Al Zarqawi [1966-2006] en Iraq, aunque dicho enfrentamiento no sea una prioridad para otros yihadistas suníes como Bin Laden o Al Zawahiri.

${ }^{32}$ El yihadismo chí́ presenta un carácter más nacionalista que el yihadismo suní, pese a los vínculos que existen entre los movimientos yihadistas chiíes (Hezbolá, Bloque Sader...) con los gobiernos de Siria e Irán y a los indicios que apuntan a acciones directas contra intereses occidentales en diferentes partes del mundo atribuidas a yihadistas chiíes.
} 
abiertamente la yihad contra EEUU e Israel, sí que los identifica como el enemigo externo del Islam. Por otro lado, el establecimiento del califato no forma parte de los objetivos del yihadismo chií, en tanto que los imanistas chiíes están a la espera del regreso del imán oculto, El Mahdi.

El surgimiento y la expansión del yihadismo islámico en las últimas cuatro décadas obedecen a varias razones. En primer lugar, a la reacción contra la violencia política (represión, encarcelamiento, tortura, ejecuciones...) empleada por algunos regímenes autoritarios de los países musulmanes contra los islamistas (Egipto, Irán, Irak, Arabia Saudí...), así como la empleada, más recientemente, por los ejércitos y los servicios secretos algunos países occidentales (EEUU, Reino Unido...).

En segundo lugar, a la expansión de los planteamientos islamistas más allá de los círculos académicos, hacia las escuelas coránicas o madrazas y las mezquitas, financiadas con recursos de los gobiernos de los países musulmanes petroleros (Arabia Saudí, Irán...), de forma que el islamismo ha pasado a convertirse en una ideología de liberación para aquellos musulmanes que se sienten oprimidos por la sociedad en la que viven.

En tercer lugar, a la utilización, la formación, la financiación y el aprovisionamiento de grupos islamistas armados, por parte de gobiernos de países occidentales (EEUU, Reino Unido...) como estrategia geopolítica de los conflictos del final de la Guerra Fría (Afganistán...), así como por parte de gobiernos islamistas (Arabia Saudí, Irán, Siria...), en su enfrentamiento contra gobiernos de países musulmanes considerados infieles (Afganistán, Líbano, Israel, Irak...).

En cuarto lugar, a la perpetuación del conflicto árabe-israelí (Palestina, Líbano, Siria, Irak...) y la presencia de tropas militares de países occidentales en territorios de países musulmanes (Arabia Saudí, Somalia, Bosnia, Afganistán, Chechenia, Irak, Líbano...), que sirven de justificación política para la yihad.

En quinto lugar, al triunfo de algunos procesos revolucionarios y golpes de Estado dirigidos por islamistas (Irán, Pakistán, Afganistán, Sudán...), que generó optimismo sobre la posibilidad de la implantación del Estado islámico en todos los países musulmanes por la vía de la exportación de la revolución islámica, y la posterior derrota militar de los islamistas yihadistas combatientes (Líbano, Pakistán, Argelia, Afganistán...), que redirigió la yihad hacia el terrorismo con la esperanza de que sirviera de catalizador para que las masas de musulmanes se sumasen a la revolución islámica.

En sexto lugar, a la marginación que sienten muchos jóvenes de los barrios más humildes de las grandes ciudades de los países musulmanes, donde existen escasas oportunidades laborales para ellos, dado que su nivel educativo es generalmente bajo, aunque suelen estar alfabetizados, así como a la que sienten los musulmanes inmigrantes residentes en países occidentales en los que, por su condición de extranjeros o por su identidad étnicocultural, se ven obligados a aceptar puestos de trabajo de inferior categoría a los de su cualificación profesional o a vivir en barrios de inmigrantes (guetos) ante la resistencia de muchos propietarios a alquilar sus inmuebles a dichos inmigrantes.

Y en séptimo lugar, al fenómeno de la globalización, que, gracias a los medios de comunicación de masas y al desarrollo de las tecnologías de la información y las telecomunicaciones, ha permitido la interconexión de grupos islamistas tradicionalmente 
aislados, y que, gracias al abaratamiento y la facilidad de acceso a los transportes, ha permitido la movilidad internacional de los yihadistas.

Así pues, podemos hablar de tres generaciones de islamistas modernos: los fundadores del islamismo moderno (Al Banna, Maududi, Qutb, Bennabi, Jomeini...); los economistas islamistas (Ahmad, Siddiqi, Chapra, Mannan, Kahf, Khan, El Ghazali, Al Sadr...); y los islamistas yihadistas (Al Zawahiri, Bin Laden, Jamenei...).

\section{Características de la Escuela Islamista del Desarrollo}

El pensamiento sobre desarrollo de la escuela islamista se puede caracterizar y condensar en los nueve puntos ${ }^{33}$.

Primero, entiende el desarrollo como el renacimiento de la sociedad islámica recuperando el esplendor que tuvo durante los tres primeros siglos de historia ${ }^{34}$ (época califal), en los que religión y política no estuvieron separados, de forma que la distribución de los recursos disponibles permita cubrir las necesidades de todos los individuos (erradicando así la pobreza) y que éstos tengan las oportunidades adecuadas para el desarrollo de su personalidad y de la más alta perfección posible ${ }^{35}$.

Segundo, considera el subdesarrollo como la decadencia de la sociedad islámica, fruto de la colonización europea, primero, y de la neocolonización estadounidense y europea, después, derivadas del alejamiento del Corán por parte de los gobernantes musulmanes, y de gran parte de la sociedad, que mal aplicaron sistemas económicos creados por el hombre (capitalismo y socialismo) en lugar de un sistema económico islámico, creado por Alá y revelado en el Corán ${ }^{36}$.

Tercero, identifica como variable clave del desarrollo el Islam, que no sólo sería un conjunto de creencias religiosas sino también un ordenamiento social, por lo que no cabría la separación entre lo religioso y lo político ${ }^{37}$.

Cuarto, propone como estrategia política el control del poder, por medio de la participación de partidos islamistas en las elecciones (opción moderada), o por medio de una revolución islámica contra las élites políticas y económicas de los países musulmanes y sus aliados estadounidenses y europeos (opción radical), para de esta forma implantar un Estado islámico, basado en el seguimiento del Corán, la tradición (sunna) y la ley islámica (sharía), como principios de la organización social y económica ${ }^{38}$.

\footnotetext{
${ }^{33}$ El esquema utilizado para identificar las características de esta escuela de pensamiento se basa parcialmente en empleado por Griffin, op. cit.

34 El período considerado de esplendor del Islam varía según los autores, de forma que hay quienes lo circunscriben incluso a los años que van desde la revelación del Corán a la muerte del Profeta Mahoma (véase Qutb, Sayyid (1949): Social Justice in Islam, ed. 2000, Nueva Cork, Islamic Publications Internacional), mientras que otros lo extienden hasta la muerte de Alí (véase Bennabi, Malek (1947): Les conditions de la renaissance: Problème d'une civilisation, ed. 1992, Argel, Societe d'Edition et de Communication).

${ }^{35}$ Maududi, Abdul Ala (1941): Economic Problem of Man and its Islamic Solution, ed. 1992, Lahore, Islamic Publications Limited; y El Ghazali, Abdel Hamid (1988): Man is the Basis of the Islamic Strategy for Economic Development, ed. 1994, Yidda, Islamic Research and Training Institute of Islamic Development Bank.

${ }^{36}$ Ibid.

${ }^{37}$ El Ghazali, op. cit.

${ }^{38}$ Jomenini, Ruhullah Musawi (1970): El gobierno islámico, ed. 1999, Granada, Kitab.
} 
Quinto, plantea que el proceso de desarrollo debe consistir en la islamización del Estado y en la posterior reunificación de la sociedad musulmana bajo un nuevo y moderno califato ${ }^{39}$.

Sexto, sostiene que la financiación del Estado islámico debe hacerse por la vía de los impuestos (zakat, sadaga, yizia, jums, jaray...) y, en algunos casos, por medio de la nacionalización de determinados recursos productivos (materias primas, petróleo...) y servicios públicos (seguridad social, banca...) ${ }^{40}$.

Séptimo, acepta la idea de que el comercio internacional entre países islámicos y no islámicos genera beneficios mutuos, siempre y cuando los contratos se acojan al derecho musulmán, pues el Corán siempre ha defendido el comercio. Algo parecido defiende respecto de otras formas de relaciones económicas internacionales, tales como los movimientos de capitales y de trabajadores, que debieran ser aceptados, salvo en los casos específicos en que no conduzcan al bienestar social de la población (para los que se aceptarían restricciones temporales a dicha movilidad) o en los que dichos movimientos sean contrarios a la sharía (como, por ejemplo, los movimientos especulativos de capital o los prestamos a interés, que estarían prohibidos) ${ }^{41}$.

Octavo, rechaza la monoeconomía, es decir, la aplicación universal de la teoría económica convencional, por entender que las características de las economías islámicas, inspiradas en el Corán, difieren mucho de las de las economías no islámicas, dado que el comportamiento económico de un buen musulmán (el hombre ético u homo islamicus) tendría muy poco que ver con el comportamiento del homo economicus de la teoría económica convencional, por lo que ésta no sería de aplicación para el desarrollo de los países islámicos ${ }^{42}$; aunque por otro lado, aspiran a la aplicación universal de la Economía Islámica ${ }^{43}$.

Y noveno, sugiere que todas las variables sociales, incluidas las variables económicas, vienen determinadas por las variables religioso-políticas, esto es, por el Islam ${ }^{44}$.

Teniendo todo esto en cuenta, la teoría islamista del desarrollo podría sintetizarse, de forma somera, de la siguiente manera. El fenómeno de subdesarrollo es un proceso de decadencia de la sociedad islámica por su alejamiento del Corán, debido al colonialismo y neocolonialismo a los que la han sometido los países occidentales. Por tanto, la mejor manera de salir del subdesarrollo es propiciar un renacimiento de la sociedad islámica por medio de la islamización del Estado y la reagrupación de la comunidad musulmana bajo un moderno califato, para lo cual es necesario el control de los gobiernos nacionales de los países islámicos por parte de auténticos musulmanes, ya sea por vías pacíficas o violentas.

Así pues, el modelo de desarrollo islamista (económico, político, social, cultural...) no es otro que la aplicación de las instituciones fundamentales del Islam, reproduciendo con ello las

\footnotetext{
${ }^{39}$ El Ghazali, Abdel Hamid (2001): The Way to the Revival of de Muslim Ummah, Al-Falah Foundation, El Cairo; Vick, Karl: "Reunified Islam: Unlikely but Not Entirely Radical. Restoration of Caliphate, Attacked by Bush, Resonates With Mainstream Muslims", Washington Post, 14 January 2006; Athena Intelligence (2007): "Hizb ut-Tahrir (HuT) en España“, Athena Intelligence Journal, vol.2, n 2, pp. 13-27.

${ }^{40}$ Al-Sadr, Mohammad Baqir (1961): Our Economics, ed. 2001, Londres, Bookextra; y Jomeini, op. cit.

${ }^{41}$ Sidiqqi, Mohammed Nejatullah: "Principles of International Economic Relations in Islam", en Muhammad Abdul Mannan, Monzer Kafh y Ausaf Ahmad (eds.) (1992): International Economic Relations from Islamic Perspectives, Yidda, Islamic Research and Training Institute of Islamic Development Bank, pp. 9-34.

${ }^{42}$ El Ghazali, Man is..., op. cit.; y Kuran, Timur (1996): "The Discontents of Islamic Economic Morality", American Economic Review, vol. 86, n 2, pp. 438-442.

${ }^{43}$ Maududi, op. cit.

${ }^{44}$ El Ghazali, Man is..., op. cit.
} 
bases políticas y económicas del esplendor material y espiritual (desarrollo) de los primeros años de la historia del Islam (que incluiría la regencia del Profeta Mahoma [622-632] y el califato de los califas ortodoxos [632-661]).

Las instituciones fundamentales del Islam, como normas que regulan el funcionamiento de una sociedad islámica son el Corán, la sharía y la sunna, y de ellas derivan otras instituciones menores (zakat, riba, mudharaba, yizia, jums, jaray, sadaga...). A partir de la aplicación de dichas instituciones puede establecerse un sistema económico islámico, fundamentado en la coexistencia de la propiedad privada con la propiedad pública, en la libertad para elegir dentro de los límites de la sharía y en la justicia social basada en la solidaridad y la equidad, y que constituyen la base económica del desarrollo. Sin embargo, dichas instituciones no se pueden aplicar si el Estado no está controlado por auténticos musulmanes, por lo que puede ser preciso recurrir a la yihad para tomar el control del Estado y para mantenerlo, al objeto de convertirlo en un Estado islámico, que termine convirtiéndose en un califato que gobierne a la toda umma; teniendo esto en cuenta, la yihad, el Estado islámico y el califato constituyen las bases políticas del desarrollo, e igualmente derivan de las instituciones fundamentales del Islam.

Conviene señalar que dicho modelo no pretenden retrotraer a la sociedad islámica hasta la Edad Media, sino reconstruir una sociedad islámica moderna sobre los mismos fundamentos (morales, políticos, económicos, sociales, culturales...) que permitieron el esplendor del califato ortodoxo; por tanto, no hay un rechazo a factores de desarrollo como el conocimiento, la ciencia o la tecnología (aspectos estos que fueron característicos del desarrollo islámico medieval), ni a otros procesos relacionados con el desarrollo, como la globalización (ya que se persigue la expansión universal del Islam y la conformación de una umma global y un califato global), la modernización de la agricultura, la industrialización, la terciarización de la economía, la expansión de las finanzas, la conformación de ETNs o los movimientos migratorios.

\section{Decadencia, dependencia y renacimiento: la reacción frente al colonialismo y el neocolonialismo}

La tesis de la decadencia-dependencia-renacimiento tiene en Qutb y Bennabi sus principales exponentes, aunque ambos se inspiran en tradición de los reformadores salafistas del siglo XIX.

En el caso de Qutb ${ }^{45}$, éste viene a sostener que, a partir de la muerte del Profeta Mahoma en el año 632, comienzan una serie de usurpaciones y traiciones (califatos de Omar, Osmán, Omeyas y Abásidas) que terminaron por implantar un régimen no islámico, a pesar de sus apariencias, amparándose en unos supuestos derechos sucesorios, cuando la comunidad musulmana o umma ha de basarse en la igualdad de los creyentes ${ }^{46}$.

Para Qutb el papel de un imán no debía ser otro que la gobernación de la sociedad musulmana por medio de la aplicación de la sharía para asegurar la existencia de un orden social islámico; y para ello no era necesaria ninguna reelaboración o actualización de la ley, sino simplemente una administración justa y una súbditos obedientes. En este sentido entiende que los califas se atribuyeron una serie de poderes que no les correspondían, ya que ni siquiera el Profeta Mahoma se denominó así mismo como representante de Alá en la Tierra por respeto a la

\footnotetext{
${ }^{45}$ Qutb, op. cit.

46 Amin, Samir (1985): “Existe una economía política del fundamentalismo islámico?”, en La desconexión. Hacia un sistema mundial policéntrico, ed. 1988, Madrid, IEPALA, pp. 333-57.
} 
comunidad $^{47}$. Los diferentes califas, con la excepción de Alí, se desviaron del Corán y de las enseñanzas del Profeta y acapararon tierras y riquezas en beneficio de una minoría que monopolizaba el poder y abusaba de él, agudizando así las desigualdades materiales entre los creyentes $^{48}$. En el caso de Bennabi ${ }^{49}$, éste considera que el período espiritual en el que los musulmanes de sacrificaban por su creencias alcanzaría hasta la muerte de Alí ${ }^{50}$.

Así pues los diferentes califatos que sucedieron al de Alí marcaron el camino de una decadencia moral que trajo consigo la colonización de los países musulmanes por parte de potencias occidentales, que profundizaron aún más las diferencias materiales entre los creyentes $^{51}$.

Bennabi $^{52}$, por su parte, profundiza en el análisis del efecto de la colonización sobre las sociedades islámicas durante la primera mitad del siglo XX, haciendo hincapié en el doble despojo que ello supuso. Por un lado, la colonización despojó a los musulmanes de sus bienes materiales (tierras, negocios...), generando un empobrecimiento brutal y general de los mismos; y por otro lado, los despojó de su cultura y su moral al imponer los valores modernizantes de la cultura occidental. Y ello tuvo a su vez tres efectos: la reducción de "lo islámico" a un mero barniz en el caso de las élites vinculadas con los colonizadores, la "indigenización" de la mayor parte de la sociedad musulmana, excluida y refugiada en los barrios marginales de las grandes ciudades; y el alistamiento de los campesinos y artesanos arruinados por la colonización en los propios ejércitos de los colonizadores ${ }^{53}$.

Pero el efecto de la colonización de los países musulmanes trascendió, según Bennabi ${ }^{54}$, más allá del proceso de descolonización, en virtud de la "colonizabilidad". Dicho concepto hace referencia al hecho de que la antigua sociedad colonizada continua construyendo su presente y su futuro en función de un esquema heredado de la colonización, lo que la conduce al camino equivocado del subdesarrollo. El impacto cultural de la colonización es tal que acaba con la cultura autóctona y destruye la autoestima de los colonizados, generando entre otras cosas un complejo de inferioridad de las clases dirigentes y un efecto demostración en el consumo de las mismas, que se materializa no sólo en la importación de bienes de consumo procedentes de las antiguas metrópolis, sino también en la importación de conceptos e ideas. Se genera de esta forma un proceso de dependencia económica y, sobre todo, cultural ${ }^{55}$.

También Qutb ${ }^{56}$ reaccionó contra las élites dominantes de los países musulmanes descolonizados o neocolonizados, a los que acusaba de haber abandonado la norma divina revelada, es decir, la sharía, para adoptar las normas paganas creadas por el hombre, como las derivadas del derecho positivo procedente de las potencias extranjeras. Dichas potencias, con intereses económicos en los países musulmanes, afianzaban en el poder a estas minorías, permitiendo con ello el mantenimiento de regímenes laicos, corruptos y autoritarios, que a su vez

\footnotetext{
${ }^{47}$ Ibid.

${ }^{48}$ Ibid., pp. 342-343.

${ }^{49}$ Bennabi, op. cit.

${ }^{50}$ Al-Ahmar, Fulla: "Sayyid Qutb and Malik Bennabi's Thought: Comparation and Constrast", Tribune Libre, 2006, en http://www.hoggar.org/pdf/Diwan/QutbBennabi.pdf, p. 6.

51 Bensaada, Mohamed (2000): “Approche socio-historique des théologies islamiques de la libération", Alternatives Sud, vol. 7, $\mathrm{n}^{\mathrm{o}} 1$.

${ }^{52}$ Bennabi, Malek (1965): Mémoires d'un témoin du siècle, Argel, Éditions Nationales Algériennes.

${ }^{53}$ Burgat, François (2005): El islamismo en tiempos de al-Qaida, ed. 2006, Barcelona, Bellaterra, pp. 22-23.

${ }^{54}$ Bennabi, Malek (1954): Vocation de l'islam, ed. 2006, Beirut, Al Bouraq.

${ }^{55}$ Bensaada, op. cit.

${ }^{56}$ Qutb, Sayyid (1966): Milestones, Nueva York - Berlin, Globusz Publishing.
} 
habían llevado a los países musulmanes a una situación de ignorancia preislámica, es decir, a que en los mismos ya no quedaran auténticos musulmanes ${ }^{57}$.

Todo ello conduce, según estos autores, a la necesidad de impulsar el renacimiento de la civilización islámica que permita el reencuentro de la sociedad islámica con el Islam. En el caso de Bennabi ${ }^{58}$, éste propone una revolución cultural islámica, una vuelta a los valores culturales derivados del Corán, ya que tanto la cultura desarrollista del capitalismo, basada en una estrategia educativa e individualista, como la cultura del comunismo, basada en una estrategia industrialista y colectivista, sólo permiten un desarrollo superficial y limitado, mientras que el verdadero desarrollo requiere de un cambio social radical basado en la islamización de la sociedad por medio de la educación.

Qutb $^{59}$, algo más radical, plantea la necesidad de volver a convertir al Islam por medio de la predicación a los que se llaman a sí mismos musulmanes, pero que no lo son, además de la necesidad de abolir todas las organizaciones y autoridades vinculadas con la ignorancia preislámica por medio de la yihad, para poder implantar un sistema político basado en la sharía. Dicho planteamiento es compartido parcialmente por Maududi ${ }^{60}$, aunque éste acepta la libertad de credo bajo el Estado islámico, proponiendo más bien una revolución desde arriba.

Una síntesis más reciente de esta tesis la presenta El Ghazali ${ }^{61}$, quien considera que el subdesarrollo de los países musulmanes no es debido a que en ello se profese la fe islámica, sino precisamente a todo lo contrario, a que son musulmanes sólo de nombre, a que han abandonado el Islam y han perdido su identidad.

Así, durante los tres primeros siglos de historia del Islam, cuando se aplicó el sistema económico islámico, la sociedad islámica floreció. Pero tras el abandono del Islam, los países musulmanes se convirtieron en pueblos débiles que pronto fueron esclavizados y explotados por otros pueblos, generando con ello subdesarrollo; algo que no sólo no se solucionó con el triunfo de los movimientos de liberación nacional y la descolonización, sino que se agravó por la aplicación inapropiada de sistemas económicos creados por el hombre. El capitalismo convirtió a los musulmanes en consumidores de los bienes manufacturados y la cultura de la civilización colonial y los oprimió y explotó; mientras que el socialismo los convirtió en consumidores de eslóganes e ideología y los oprimió y explotó aún más. Además la aplicación de estos sistemas en los países musulmanes no permitió alcanzar los mismos resultados que el los países desarrollados debido a que el choque entre las ideologías impuestas y las profundas creencias religiosas de los musulmanes, creó una psicología de ambivalencia y dislocación, una inercia social y una entropía que desembocaron en un declive económico que generó hambre, enfermedad, analfabetismo, drogadicción, desertificación, despilfarro de recursos, mínima productividad, subordinación a intereses extranjeros, deuda externa... características todas ellas de la situación de subdesarrollo. La solución a este problema estaría por tanto en la aplicación de un sistema económico islámico ${ }^{62}$.

\footnotetext{
${ }^{57}$ Burgat, op. cit., pp. 119 y 123.

${ }^{58}$ Bennabi, Malek (1955): Le problème de la culture, Dar al fiar, Beirut.

${ }^{59}$ Qutb, Milestones, op. cit.

${ }^{60}$ Maududi, Abdul Ala (1939): Jihad in Islam, ed. 2006, Beirut, The Holy Koran Publishing House.

${ }^{61}$ El Ghazali, Man is..., op cit., pp. 15-16 y 37-39.

${ }^{62}$ Ibid.
} 


\section{El sistema económico islámico: Las bases económicas del desarrollo}

Las primeras referencias de la literatura a lo que se ha venido en llamar el sistema económico islámico las encontramos en el ensayo de Maududi sobre el "problema económico del hombre" ${ }^{\text {"63 }}$. Dicho problema consistiría en cómo conseguir que la distribución de los recursos disponibles permita cubrir las necesidades de todos los individuos y que éstos tengan las oportunidades adecuadas para el desarrollo de su personalidad y de la más alta perfección posible de acuerdo a su personalidad y actitud ${ }^{64}$.

Para Maududi ${ }^{65}$, ni el capitalismo, ni el socialismo, ni el fascismo, consiguen solucionar dicho problema económico, porque son sistemas económicos creados por el hombre que separan lo económico del resto de los asuntos de la vida humana. Por el contrario la solución a dicho problema estaría en el Islam, la solución islámica, ya que la religión plantea el problema económico dentro del conjunto de problemas de la vida del hombre, por lo que bastaría con aplicar el Corán y la sharía, para desarrollar un sistema económico islámico, en este caso creado por Alá.

Siguiendo los planteamientos de Maududi ${ }^{66}$, diferentes economistas islamistas han intentado concretar en qué consiste un sistema económico islámico y han desarrollado la llamada "Economía Islámica"67. Dicha concepto hace referencia al conocimiento y a la aplicación de aquellos mandamientos y normas de la sharía que previenen la injusticia en la adquisición y la disposición de los recursos materiales necesarios para proveer satisfacción a los seres humanos y permitirles cumplir sus obligaciones con Alá y la sociedad ${ }^{68}$. La Economía Islámica se basaría en tres pilares: la coexistencia de la propiedad privada y la propiedad pública; la libertad económica dentro de los márgenes de la sharía; y la justicia social basada en la solidaridad y la equidad ${ }^{69}$.

Los economistas islamistas, como Chapra $^{70}$, consideran que el sistema económico debe permitir la satisfacción de las necesidades de los seres humanos, tanto materiales como espirituales; y si bien las necesidades materiales pueden ser satisfechas mediante el mercado, o por la acción del Estado, las necesidades espirituales sólo pueden satisfacerse moldeando el comportamiento individual y social mediante la aplicación de la sharía. La no satisfacción de las necesidades materiales y espirituales de los seres humanos llevaría a una anomia, que desembocaría en frustración, crimen, alcoholismo, drogadicción, divorcio, enfermedades mentales, suicidio $^{71} \ldots$

\footnotetext{
${ }^{63}$ Maududi, Economic Problem..., op. cit.

${ }^{64}$ Maududi entiende ya tempranamente el desarrollo como satisfacción de necesidades y aumento de oportunidades de los individuos, pudiendo ser considerado por ello un precursor del concepto de "desarrollo humano" (ibid., p. 11). Para otros autores, el "problema económico del hombre" no sería sólo un problema de distribución sino también de negligente explotación de los recursos disponibles (Al-Sadr, Mohammad Baqir (1961): Our Economics, ed. 2001, Londres, Bookextra, p. 638).

${ }^{65}$ Maududi, Economic Problem..., op. cit.

${ }^{66}$ Maududi, Economic Problem..., op. cit.

${ }^{67}$ En Chapra, Muhammad Umer (1996): What is Islamic Economics? Yidda, Islamic Research and Training Institute (Islamic Development Bank), pp. 33-34, se encuentran varias definiciones de "Economía Islámica"; aunque, a pesar de dicha expresión, el concepto hace más bien referencia a lo que podríamos denominar "Economía Política Islamista", al combinar variables políticas y económicas con una importante orientación ideológica; de ahí lo de "islamista" en lugar de "islámica".

${ }^{68}$ Hasanuzzaman, S. M.: "Definition of Islamic Economics", Journal of Research in Islamic Economics, vol. 1, $\mathrm{n}^{\mathrm{o}} 2$ (winter 1984), p. 52.

${ }^{69}$ Al Sadr, op. cit., pp. 280-286.

${ }^{70}$ Chapra, op. cit.

${ }^{71}$ Ibid., p. 25.
} 
La sharía actúa como un filtro moral que cambia las preferencias de los seres humanos de acuerdo con las prioridades sociales. Este filtro moral no sustituye el papel del mercado sino que lo complementa, permitiendo armonizar los intereses individuales con los intereses sociales; algo que no garantizaría el mercado. Además, dicho filtro permite minimizar el uso de recursos para propósitos que no contribuyan a alcanzar los dos principales fines morales vinculados con el desarrollo, esto es, la justicia socio-económica y el bienestar social ${ }^{72}$. Y la motivación para no cruzar los límites de esos fines morales estaría en el Más Allá, en el que los individuos deberán rendir cuentas por sus acciones ante Alá, quien los castigará o premiará ${ }^{73}$.

De hecho los economistas islamistas, como El Ghazali ${ }^{74}$, consideran que todos los recursos pertenecen a Alá y que el hombre es sólo su vicegerente, el cual puede hacer uso de ellos en beneficio propio, al tiempo que debe aumentarlos con su esfuerzo; como contrapartida de la deuda del hombre con Alá y la sociedad islámica, éste debe practicar la caridad, gestionando así de forma equitativa la riqueza, estableciendo con ello un sistema de solidaridad social y asegurando un uso óptimo de la riqueza en el tiempo.

Pero para que exista un ambiente socioeconómico adecuado para alcanzar los fines morales de justicia socioeconómica y bienestar social se precisa también de una serie de reformas socioeconómicas y financieras, sin las cuales muchos países musulmanes podrían sufrir importantes desequilibrios macroeconómicos que impidieran el logro de los fines morales. Así pues, el Estado islámico ha de jugar un papel activo en la conformación del sistema económico islámico $\mathrm{y}$, junto con las tradicionales funciones ${ }^{75}$ de proveer seguridad interna e externa y corregir las imperfecciones y fallos del mercado, ha de encargarse también de determinar las prioridades sociales y de reformar los gustos, las preferencias y las conductas de los individuos, además de las instituciones que los afectan, aunque ello suponga limitar la soberanía del consumidor $^{76}$. Así mismo sería función del Estado islámico la provisión de un seguro social, ante la negligencia de muchos musulmanes en el cumplimiento de su deber de asistencia a los necesitados o cuando su adecuado cumplimento sea insuficiente para cubrir las necesidades de los más desfavorecidos, e incluso más allá de la cobertura de dichas necesidades, en función del derecho de la comunidad islámica al disfrute de las fuentes de la riqueza ${ }^{77}$.

Las citadas reformas habrían de ejecutarse, preferiblemente sin coerción, generando una dimensión moral en el mercado, de forma que el consumidor restrinja voluntariamente su soberanía para acomodar sus intereses individuales con los intereses sociales; así, las instituciones socioeconómicas y políticas que influyen en la conducta de los individuos se reformarían por la acción estatal, mientras que los gustos y preferencias de los consumidores se reformarían por medio de la educación. Una educación que, entre otras cosas, debe inculcar la

\footnotetext{
${ }_{72}$ Dichos fines son denominados por otros autores como "equilibrio" o "equidad social", el primero, y como "solidaridad" o "seguridad social", el segundo.

${ }^{73}$ Ibid., pp. 25-28.

${ }^{74}$ El Ghazali, Man is..., op. cit.

${ }^{75}$ Otros autores señalan entre las funciones del sector público de un Estado islámico, además de la creación de un ambiente adecuado, la de desarrollar infraestructuras y bienes públicos y la de producir aquellos bienes y servicios que el sector privado no produce por su escasa rentabilidad, su elevado riesgo, su tamaño de planta o su lenta recuperación de la inversión (El Ghazali, Man is..., op. cit., pp. 49-50). También los hay que consideran que el Estado islámico, además de aplicar la sharía, debe legislar sobre aquellos aspectos que la misma no cubre ("zona de vacío") para adaptar la legislación islámica a las cambiantes circunstancias, lo que incluiría todo tipo de intervención del Estado en el mercado, incluyendo la nacionalización de recursos naturales y servicios públicos (Al Sadr, op. cit., pp. 628-631, 655 y 681).

${ }^{76}$ Chapra, op. cit., pp. 29-32.

${ }^{77}$ Al Sadr, op. cit., pp. 659-664.
} 
preferencia por una vida simple y por la reducción del consumo de lujo, liberando así recursos que podrían destinarse a la inversión, la creación de empleo y el crecimiento económico ${ }^{78}$.

Así, las reformas generarían un equilibrio del mercado que permitiría obtener una óptima combinación entre eficiencia y equidad; entendiendo por eficiencia, el uso de todo el potencial de los recursos materiales y humanos para producir el máximo de bienes y servicios para satisfacer las necesidades humanas con un grado razonable de estabilidad y una tasa de crecimiento económico sostenible; y por equidad, la distribución equitativa de la riqueza, de la renta y de los bienes y servicios producidos de forma que todas las necesidades de los individuos sean adecuadamente satisfechas sin afectar a la motivación al trabajo, al ahorro, a la inversión y al emprendimiento ${ }^{79}$.

No obstante, en la conformación del sistema económico islámico deben tenerse en cuenta dos importantes instituciones islámicas, la limosna o zakat y la prohibición de la usura o riba. Mientras la limosna es la base del todo el sistema fiscal, la prohibición de la usura es la base de todo el sistema financiero.

El sistema impositivo islámico estaría formado por cuatro importantes impuestos: la limosna o zakat, que pagarían los musulmanes sobre los beneficios obtenidos del capital y de las actividades agrícolas y ganaderas y por la acumulación de riqueza; la capitación o yizia, que pagarían per cápita los no musulmanes a cambio de los servicios del Estado islámico (estando con ello exentos del zakat y el jums); el quinto o jums, que se aplicaría como la quinta parte del resultado de la explotación de los recursos naturales y a los beneficios agrícolas, industriales e inmobiliarios, etc.; y el jaray, que se aplicaría a las tierras liberadas por los musulmanes ${ }^{80}$; a ellos habría que sumar la expiación o sadaga, que, pese a ser una limosna voluntaria que pagaría los musulmanes para expiar sus culpas, también debe ser recaudada por el Estado islámico al estar vinculada al zakat; además de otros impuestos que dicho Estado establezca en función de su capacidad legislativa según las cambiantes circunstancias ${ }^{81}$. De todos ellos, sin duda, el zakat es el más importante, en tanto que constituye uno de los cinco pilares del Islam ${ }^{82}$.

La importancia del zakat reside en que se trata de un impuesto finalista, en este caso encaminado a la lucha contra la pobreza, al igual que la sadaga, y que no puede ser recibido por aquellos que tienen posibilidad de ganarse la vida por sí mismos; por tanto, se trata de un mecanismo de redistribución de la renta y la riqueza. Por otro lado, como el zakat funciona, además de como impuesto de la renta del 2,5\%, como un impuesto de patrimonio del 2,5\% sobre el oro, la plata y el dinero en efectivo acumulado durante más de un año, supone también un importante estímulo para aumentar la demanda de los musulmanes, ya sea por la vía del consumo o de la inversión. Dicho estímulo se ve reforzado, por otro lado, por la participación de los pobres que reciben el zakat tanto en el consumo como en la producción ${ }^{83}$.

El consumo de los musulmanes, por su parte, debe basarse en las siguientes prioridades: en primer lugar, las cosas sin las cuales la vida no podría continuar; en segundo lugar las cosas sin las cuales la vida sería muy dura; y en tercer lugar, las cosas accesorias para vivir bien sin

\footnotetext{
${ }_{78}^{78}$ Chapra, op. cit., pp. 29 y 32.

${ }^{79}$ Ibid., p. 31.

${ }^{80}$ Jomeini, op. cit., pp. 35-51.

${ }^{81}$ Al Sadr, op. cit., p. 676.

${ }^{82}$ El Ghazali , Man is..., op. cit., pp. 47-48.

${ }^{83}$ Ibid., p. 48.
} 
excesos ni extravagancias. El consumo suntuario, por tanto, no les estaría permitido a los musulmanes ${ }^{84}$.

La inversión de los musulmanes, y todo el sistema financiero, estaría basada en la institución de la prohibición de la usura o riba, lo cual supone la prohibición de todo tipo de préstamos a interés, salvo que el mismo conlleve la asunción de un riesgo más allá de la morosidad o el impago; es decir, que una ganancia sólo sería legítima si ha existido un riesgo real de pérdida. La importancia de todo esto reside en el hecho de modificar el papel de los bancos islámicos como intermediarios financieros, ya que, en lugar ser garantes de los depósitos recibidos, se convierten en fideicomisarios de los mismos en un proceso de inversión islámica; inversión que se caracteriza porque el propietario del capital invierte conjuntamente con el empresario en un proyecto y comparte con éste tanto las ganancias como las pérdidas en función de un contrato ${ }^{85}$. Un banco islámico actuaría así como empresario para los depositantes, que serían los inversores, y como inversor para los empresarios a los que financian sus proyectos. Además de la participación de la banca en la inversión, también existen sociedades mercantiles islámicas e inversiones individuales, que igualmente deben acogerse a la jurisprudencia islámica ${ }^{86}$.

No obstante, la prohibición de la riba no es único mecanismo de control directo que ejercería un Estado islámico en el mercado, sino que existen un gran número de controles por medio de los cuales se persigue un funcionamiento de dicho mercado acorde con la sharía. Entre dichos controles destacan: la prohibición del gharar o ambigüedad o gran incertidumbre en los contratos, como podrían ser las apuestas o la especulación; la prohibición del fraude en pesos y medidas; la prohibición del monopolio; la prohibición del acaparamiento de bienes de primera necesidad; la prohibición del atesoramiento; la prohibición del despilfarro; la prohibición de la tacañería; la prohibición de la ociosidad; y en general la prohibición de toda forma ilegal de la riqueza ${ }^{87}$. Más allá de dichos controles, el Estado islámico podría ejercer su hegemonía sobre la explotación de las materias primas ${ }^{88}$.

Por otro lado, los economistas islamistas, como Siddiqi, consideran que las relaciones económicas exteriores del sistema económico islámico también deberían regirse por la sharía y responder así a tres objetivos principales: preservar y promover el interés económico de la población nacional, priorizando sobre la satisfacción de las necesidades; observar la sharía en las transacciones económicas para asegurar las justicia y la equidad; y extender la comunidad de creyentes o umma, por medio de la cooperación con otros países islámicos, para que el Islam se convierta en un ejemplo para otras naciones, y la promoción del bienestar humano en el ámbito global $^{89}$. Así, los mismos controles directos vinculados con las prohibiciones de la sharía afectarían igualmente a las relaciones económicas exteriores.

En principio, la aplicación de la sharía supone la aceptación de la libre circulación de productos y factores dentro de los límites de la misma; sin embargo, cuando la contraparte de las relaciones exteriores de un país islámico aplica medidas que pueden perjudicar la consecución de

\footnotetext{
${ }^{84}$ Ibid., p. 49.

${ }^{85}$ En caso de pérdida el empresario pierde su trabajo y el inversor su dinero y en caso de beneficio éste se reparte según los porcentajes determinados en el contrato; a este tipo de forma de reparto del riesgo se le denomina contrato mudharaba y que, aunque es la base de la banca islámica, no es el único tipo de contrato en que puede participar un banco islámico.

${ }^{86}$ Ibid., pp. 50-51.

${ }^{87}$ Ibid., pp. 53-54.

${ }^{88}$ El Sadr, op cit., p. 655.

${ }^{89}$ Siddiqi, "Principles of...", op. cit., p. 16.
} 
los fines morales de justicia y equidad, dicho país podría aplicar recíprocamente restricciones a dicha movilidad, a menos que se trate de perjuicios temporales derivados de una leal competencia. Por otro lado, al tener en cuenta que en la actualidad los países islámicos son países en desarrollo, éstos se encontrarían en inferioridad de condiciones para enfrentarse a la libre competencia en los mercados internacionales y, mientras no cambie esta situación, la aplicación de restricciones a la movilidad de productos y factores resultaría beneficiosa para su desarrollo; restricciones que deberían de adaptarse a los cambios que se produjesen en el contexto internacional y el desarrollo de los países islámicos ${ }^{90}$.

No obstante, la mejor política para evitar los perjuicios del proteccionismo y contribuir a un orden mundial más justo sería la firma de acuerdos internacionales de libre movilidad de productos y factores, tanto con países islámicos como no islámicos, que serían de obligado cumplimiento, a menos que sus compromisos sean contrarios a la sharía o hayan sido firmados bajo coacción ${ }^{91}$.

Por lo que se refiere a las restricciones comerciales, la aplicación de aranceles y de otras formas de proteccionismo sólo serían admisibles ante la ausencia de acuerdos internacionales que protejan los intereses de los países productores de productos primarios $\mathrm{y}$, de manera recíproca, en función de las restricciones impuestas por las contrapartes ${ }^{92}$.

En materia de circulación de trabajadores, si bien ésta sería deseable, mientras persistan importantes diferencias de niveles educativos y de vida entre unos países y otros, se justificaría que los países islámicos con mayores niveles de ingresos limitasen la entrada de trabajadores extranjeros, en aras a poder ordenar su mercado de trabajo y dar la debida protección por desempleo a sus ciudadanos; a menos que exista escasez de mano de obra en dichos países, en cuyo caso las limitaciones debieran reducirse. Así mismo, los países islámicos podrían limitar la salida de trabajadores cualificados en función de las necesidades del desarrollo nacional y como compensación por los recursos invertidos en la formación de los mismos; a menos que no existan puestos de trabajo disponibles para ocupar a dichos trabajadores cualificados. Por otro lado, teniendo en cuenta que la entrada de trabajadores extranjeros en un país aumenta la productividad y la salida de trabajadores aumenta las entradas de divisas en forma de remesas, la libre circulación de trabajadores se considera deseable y su restricción sólo se justificaría de manera temporal ${ }^{93}$.

Algo similar sucedería con los movimientos de capitales, que en principio serían considerados como positivos, pero que podrían ser restringidos si con ello se contribuye mejor a alcanzar los fines morales de justicia y equidad o si los mismos implican prácticas prohibidas por la sharía. Así, por ejemplo, se justificaría: la regulación de los mercados nacionales de capitales, para que éstos sean conformes con las reglas de la sharía; las limitaciones de las inversiones extranjeras de los nacionales, para que inviertan en el desarrollo de sus propios países; las limitaciones a la entrada de capital extranjero como vía de financiación, dada su vinculación con el préstamo a interés o la especulación, optando preferentemente por la ayuda oficial al desarrollo o por préstamos sin interés; y la regulación de las inversiones de las empresas transnacionales, condicionándolas a la participación del capital nacional en los proyectos empresariales o a la transferencia de tecnología. No obstante, bajo excepcionales circunstancias

\footnotetext{
${ }^{90}$ Ibid., pp. 17-18 y 21.

${ }^{91}$ Ibid., p. 19.

${ }^{9}$ Ibid., p. 23.

93 También se considerarían como restricciones temporales la limitación de entrada de trabajadores no musulmanes en países islámicos en aras a no someter a los musulmanes a los riesgos de su exposición a un ambiente cultural no islámico (ibid., p. 24).
} 
de necesidad extrema, un país islámico podría aceptar temporalmente préstamos a interés de otras naciones, de la banca comercial extranjera o de organismos públicos extranjeros, en función de la aplicación de las máximas incluidas en la sharía, tales como de del mal menor ${ }^{94}$.

Los tipos de cambio también han sido objeto de preocupación por los economistas islamistas, en la medida en que la libre flotación de los mismos en los mercados de divisas genera una gran incertidumbre a la hora de diseñar políticas de desarrollo para los países islámicos. Así, aunque manifiestan una cierta preferencia por tipos de cambio fijos, asumen que los mismos no son viables en el actual escenario monetario internacional, por lo que optan por defender la creación de instituciones financieras islámicas que puedan ayudar a estos países en los momentos en que tengan desequilibrios exteriores y contribuir a reducir la incertidumbre ${ }^{95}$. Algunos autores han llegado a defender el uso del "dinar de oro islámico" como moneda común para los países islámicos, o al menos como moneda de cambio para las transacciones internacionales entre países islámicos ${ }^{96}$.

Por lo que se refiere a la integración económica regional, ésta aparece como una necesidad en el objetivo de ampliar la comunidad de creyentes o umma; así se defiende la necesidad de la cooperación económica y la creación de una unión de pago, una unión monetaria, una unión aduanera y un mercado único entre los países miembros de la Organización de Países Islámicos, que formarían una región geográficamente continua que va desde el Norte de África al Sudeste de Asia pasando por Asia Occidental. Además a dicho proceso de integración podría invitarse a participar a otros países vecinos no islámicos con la esperanza de su conversión ante el buen ejemplo del Islam ${ }^{97}$.

En materia de cooperación económica, ésta debe realizarse principalmente entre países islámicos, aunque también cabría la posibilidad de realizar acuerdos de cooperación con países no islámicos en los que existan minorías islámicas, al objeto de conseguir un tratamiento justo por parte de los países donde dichas minorías residen. Así mismo, se debe cooperar directamente con las propias comunidades islámicas residentes en países no islámicos, en particular en materia de educación, de empleo y de negocios ${ }^{98}$.

Por ultimo, conviene señalar que la mayoría de los economistas islamistas consideran que el sistema económico islámico es una construcción teórica que algún día debiera implantarse en los países musulmanes y no refleja funcionamiento de la economía de los países musulmanes, salvo, tal vez, en los casos excepcionales de Arabia Saudí, el Afganistán de los talibanes, en la variante suní, o el Irán de los ayatolás, en la variante chií.

\section{La yihad, el estado islámico y el califato: las bases políticas del desarrollo}

La implantación real del sistema económico islámico supone necesariamente que la dirección política de los países musulmanes esté en manos de líderes político-religiosos fieles al Islam, y ello no sucede en la mayoría de dichos países, por lo que se hace necesaria la yihad.

\footnotetext{
${ }^{94}$ Ibid., pp. 25-26.

${ }^{95}$ Ibid., p. 27.

${ }^{96}$ Hanafi, Khaled (2003): "Islamic Gold Dinar Will Minimize Dependency on U.S. Dollar", IslamOnline, (08 January 2003), en http://www.islamonline.net/english/news/2003-01/08/article08.shtml.

${ }^{97}$ Siddiqi, "Principles of...", op. cit., pp. 28-31.

${ }^{98}$ Ibid., p. 30.
} 
Este término hace referencia al "esfuerzo en la defensa del Islam" y, como tal, tiene muchas interpretaciones; aunque la más conocida es la de "guerra santa" contra los infieles, y así es entendida por los islamistas yihadistas modernos, tales como Al Banna, Muadudi y Qutb, que serían sus fundadores, o Bin Laden y Al Zawahiri, que serían sus principales defensores en la actualidad.

La yihad de los fundadores, en especial Maududi y Qutb ${ }^{99}$, iba dirigida fundamentalmente contra las potencias coloniales que ocupaban los países islámicos e impedían el establecimiento de un gobierno islámico (como el caso de la parte musulmana de la India como colonia británica) y contra el nacionalismo árabe imperante en los países musulmanes descolonizados pero dependientes cultural, económica y políticamente de las potencias extranjeras (como el caso del Egipto de mediados del siglo XX). No obstante, Maududi ${ }^{100}$ sostiene que la yihad ha de dirigirse a destruir todos los Estados y gobiernos infieles por medio de una revolución universal que elimine los sistemas políticos no islámicos e instaure en todo el mundo el sistema islámico como forma de gobierno; dicho sistema estaría referido a la administración del Estado, permitiéndose la libertad de culto, siempre y cuando ésta no afecte negativamente al interés público.

Sin embargo, el primer gran llamamiento moderno a la yihad, lo realizó Bin Laden ${ }^{101}$ en un decreto religioso o fatwa, en que reacciona contra el neocolonialismo estadounidense y el impío regímen saudí. Este yihadista ordena a todos los musulmanes hacer la yihad contra los "cruzados y sionistas", es decir, contra los soldados estadounidenses que ocupan las tierras sagradas de los musulmanes (Meca y Medina) y sus aliados israelíes; dicha yihad tendría dos variantes, la militar, organizada como "guerra de guerrillas" (terrorismo), y la económica, organizada como "boicot" a todos los productos estadounidenses; el planteamiento de Bin Laden es inflingir tanto daño a Estados Unidos, que se vean obligados a abandonar Arabia Saudí, para posteriormente poder deponer a la impía monarquía saudí e instaurar un verdadero Estado islámico en la península arábiga; Estado que debería aportar la prosperidad económica correspondiente al principal exportador de petróleo del mundo.

El segundo llamamiento moderno a la yihad, lo realizaron Bin Laden, Al Zawahiri y otros tres líderes yihadistas ${ }^{102}$, como representantes del Frente Islámico Mundial, en otra fatwa en la que se ordena a todos los musulmanes "matar a los americanos y a sus aliados (civiles y militares)" y "arrebatarles su dinero donde y cuando los encuentren" para que "aprendan la lección" y sus ejércitos abandonen todas las tierras del Islam. Y aunque no se hace explícita, la finalidad de dicha yihad sería igualmente la instauración del Estado islámico en los países musulmanes liberados de la ocupación extranjera.

Esta segunda fatwa supone, en cierto modo, la "globalización de la yihad", en la medida en que los objetivos de liberación no se circunscriben a un país determinado, sino al conjunto de tierras del Islam, además de aparecer firmada por los representantes del Frente Islámico Mundial. De hecho, ambas fatwas, llevan implícita la "tesis de enemigo lejano y del enemigo cercano" de

\footnotetext{
${ }^{99}$ Maududi, Jihad in ..., op. cit. y Qutb, Milestones, op. cit.

${ }^{100}$ Maududi, Jihad in ..., op. cit., pp. 8-28.

${ }^{101}$ Bin Laden, Osama: "Declaration of War against the Americans Occupying the Land of the Two Holy Places", Al-Sharq al-Awsat, (August 1996), Londres, en http://www.pbs.org/newshour/terrorism/international/fatwa_1996.html.

${ }^{102}$ Bin Laden, Osama, Al Zawahiri, Aiman, Ahmad Taha, Ābu-Yasir Rifa'i, Hamzah, Shaykh Mir, y Rahman, Fazlur: "Jihad against Jews and Cruzaders", PBS Newshour, 23 February 1998, en http://www.pbs.org/newshour/terrorism/international/fatwa_1998.html.
} 
Al Zawahiri ${ }^{103}$, según la cual para poder implantar el Estado islámico es preciso derrotar al enemigo cercano, que son los gobiernos impíos de los países musulmanes, y ello no puede hacerse debido a que dicho enemigo cuenta con el apoyo militar de gobiernos extranjeros no musulmanes (Estados Unidos y sus aliados), que serían un enemigo lejano al cual hay que derrotar previamente. Dicha tesis supone que son objetivos de la yihad todos los ciudadanos occidentales y sus riquezas, en la medida en que son el soporte del enemigo lejano, así como todos aquellos supuestos musulmanes que son el soporte de los gobiernos impíos de los países musulmanes. De hecho Al Zawahiri ${ }^{104}$ señala como objetivos de la yihad internacional a los instrumentos de lucha del enemigo lejano, que serían: las Naciones Unidas; los gobiernos aliados de los países musulmanes; las corporaciones multinacionales; las agencias internacionales de noticias y las redes internacionales de medios de comunicación; y las agencias de ayuda internacional que son usadas para hacer espionaje, proselitismo, planificación de golpes de Estado y transferencias de armas.

Por lo que se refiere a yihadismo chí, éste contaría con dos importantes representantes, Jomeini, como fundador, y Jamenei ${ }^{105}$, como impulsor del yihadismo chií actual. El caso de Jomeini, éste llamaba a la yihad contra el gobierno impío de Persia, apoyado por Estados Unidos, para derrocarlo y establecer un Estado islámico en Irán, como de hecho se consiguió. Jamenei ${ }^{106}$, por su parte, llama a los chiíes a enfrentar la agresión del "enemigo externo", es decir, del "régimen de dominación internacional" representado por la red del sionismo internacional y el gobierno de Estados Unidos, incluso más allá de las leyes internacionales, en una clara alusión a la yihad contra "transgresores, invasores y provocadores de guerra".

Así pues, para los yihadistas, una vez liberadas las tierras del Islam, procedería la implantación del Estado islámico, que no sería otra cosa que la instauración de la sharía como ley suprema del Estado y el depósito del poder político en manos de líderes religiosos. Sobre la conformación de este Estado islámico es donde existen las principales diferencias entre yihadistas suníes y chíes, ya que mientras los primeros defienden el califato, los segundos optan por la regencia del sabio o welayat faqí.

Los imanistas chiíes están a la espera del regreso del imán oculto, El Mahdi, y su tradición ha interpretado que no cabía la posibilidad de que ningún musulmán ocupase el puesto de imán; es por ello que durante siglos los clérigos chiíes no se han preocupado de los asuntos políticos más que como supervisores. Sin embargo, con la irrupción del islamismo chí́ de Jomeini ${ }^{107}$, se quebró dicha tradición con la elaboración que él mismo hizo de la "tesis de la regencia del sabio" o welayat faqí, según la cual, en ausencia de El Mahdi, los asuntos políticos no debían dejarse en manos de cualquier persona, sino que debían estar en manos de un clérigo experto en la ley islámica; sólo un sabio puede aplicar correctamente la sharía en ausencia del imán oculto y hasta que, con el regreso de éste, se reinstaurase el imanato. Así, tras la revolución islámica de Irán, el propio Jomeini, primero, y Jamenei, después, habrían ocupado el cargo de Líder Supremo, equivalente a la welayat faqí; por tanto, no cabe dentro del islamismo chií la defensa de la reinstauración del califato (o imanato, en la variante chií), ya que ésta sólo se produciría tras la llegada de El Mahdi.

\footnotetext{
${ }^{103}$ Al-Zawahiri, op. cit.

${ }^{104}$ Al-Zawahiri, op . cit.

105 Jomeini, op. cit., y Jamenei, Alí Huseini (2007): "El enemigo interno, el enemigo externo y la guerra psicológica", en http://www.islamoriente.com/articulos/lider/enemigo-int-y-ext.htm.

106 Jamenei, op. cit. y Jamenei, Alí Huseini (2005): "El despertar islámico y la amenaza de la arrogancia mundial”, en http://www.islamoriente.com/articulos/lider/despertar-islamico.htm.

107 Jomeini, op. cit.
} 
Dicha defensa sí es sostenida por los suníes que identificarían el Estado islámico con el califato. Uno de los primeros defensores de la conformación de un Estado islámico como califato fue Maududi ${ }^{108}$. Este autor defendió el establecimiento gradual del Estado islámico por medio de la aplicación de la sharía y sostiene que el sistema político del Islam es lo que el denomina la "teodemocracia". Dicho concepto, como gobierno democrático divino, hace referencia a que la soberanía recae en Alá, que retiene la capacidad de legislar para sí mismo, y lo hizo por medio de una ley islámica inmutable (sharía), como forma de proteger al hombre de sí mismo; ello supone que los musulmanes, en cuanto vicegerentes de Alá, tienen una soberanía popular limitada por la sharía, dentro de la cual pueden legislar y ejercer su libertad ${ }^{109}$. Además en el Estado islámico, todo musulmán adulto y sano, sea hombre o mujer, tiene libertad de expresión en cuanto califa de Alá que es ${ }^{110}$.

Sobre el califato, Maududi ${ }^{111}$ sostiene que la vicegerencia de Alá, o califato, recae en el conjunto de la comunidad de creyentes, por los que todos y cada uno de los musulmanes son califas de Alá, sin que ninguno sea superior a otro por razones de familia, clase o raza, siendo las únicas diferencias admitidas en el orden social islámico las derivadas de la capacidad personal y el carácter. Dado que ningún califa es inferior a otro, no hay lugar para la dictadura en el Islam.

Así la persona que es seleccionada para dirigir los asuntos del Estado islámico, es sólo el califa en el que los demás califas han delegado su califato con fines administrativo; por eso, el califa delegado responde de sus actuaciones ante Alá y ante el resto de los califas, es decir, ante la comunidad de creyentes. En este sentido, el califa delegado tiene su mandato limitado por Alá mediante la sharía, la ley islámica que debe cumplir y hacer cumplir.

Otros islamistas suníes como los yihadistas o los miembros del Partido de la Liberación, también han defendido más recientemente el califato, pero desde una perspectiva territorial. Para estos autores, las tierras liberadas del Islam deberían estar bajo el gobierno de un único líder político-religioso elegido por la comunidad de creyentes o umma, que recibiría el título de califa o sucesor del Profeta.

Desde la disolución del califato otomano en 1926 por el gobierno secular turco, la idea de reinstaurar un nuevo y moderno califato ${ }^{112}$ ha estado presente en el pensamiento de los islamistas, incluidos Al Banna, Maududi, Qutb, Al Zawahiri y El Ghazali ${ }^{113}$; de hecho los yihadistas llegaron a constituir lo que consideraron el corazón del nuevo califato en el Afganistán de los talibanes bajo liderazgo del Mulá Omar, al que otorgaron el título de "Comandante de los Creyentes", equivalente al título de califa. Sin embargo, tras la caída del régimen talibán y tras el inicio de la insurgencia en Irak, los yihadistas han propuesto la creación de un emirato en este país, como paso previo para la reinstauración del califato ${ }^{114}$.

\footnotetext{
${ }^{108}$ Maududi, Jihad..., op. cit. y Maududi, Abdul Ala (1955): The Islamic Law and Constitution, ed. 1960, Lahore, Islamic Publications Limited.

${ }^{109}$ Maududi, The Islamic Law..., op. cit., pp. 138-147.

${ }^{110}$ Ibid., pp. 151-152.

111 Ibid., pp. 148-152.

${ }^{112}$ No en todos los casos se utiliza abiertamente el término "califato", pero sí el concepto de un Estado islámico unificado bajo liderazgo político-religioso de una persona formada en la fe islámica (sea ulema o no).

113 Al-Banna, Hassan (n.d.): Majmu'at al Rasa'il al-Iman al-Shaheed Hassan al-Banna, ed. 1980 en árabe, Alejandría, Dar al-Da'wa; Maududi, Jihad..., op. cit.; Maududi, The Islamic Law..., op. cit.; Qutb, Milestones, op. cit.; Al-Zawahiri, Ayman (2005): "Letter from Al-Zawahiri to Zarqawi", en http://www.fas.org/irp/news/2005/10/letter_in_english.pdf; y El Ghazali, The Way to..., op. cit.

${ }^{114}$ Al Zawahiri, "Letter from...", op. cit.
} 
Sin embargo, la defensa intelectual de la instauración del califato, como sinónimo de un Estado islámico unificado, viene siendo sostenida también por islamistas de los Hermanos Musulmanes, siguiendo las enseñanzas de Al Banna, y por los del Partido de la Liberación o Hizb ut Tahrir, quienes han propuesto la creación de un califato en Asia Central para después ir extendiéndolo por el resto de las tierras del Islam.

Desde Hizb ut Tahrir se sostiene que el califato sería un macroestado islámico dividido en provincias que englobaría, en primer lugar, a todos los países de mayoría musulmana para, posteriormente, ir extendiéndose por todo el mundo a medida que la umma ocupase todo el planeta; dicho Estado estaría bajo el mando de un califa que gobernaría conforme a la sharía, y que sería elegido por votación de la umma de entre los candidatos propuestos por el Consejo de la Umma ${ }^{115}$. El Ghazali, por su parte, como líder de los Hermanos Musulmanes, sostiene que la reconstrucción del califato islámico, que ha de ser universal, debe seguir una serie de pasos como son la cooperación cultural, social y económica, la firma de acuerdos políticos, la celebración de conferencias y encuentros, la creación de una Liga Islámica de Naciones y la elección de un imán (califa); además, la construcción del califato global ha de hacerse respetando las leyes y tratados internacionales (tanto de paz como de guerra), excluyendo el racismo, la intolerancia y la discriminación religiosa, desarrollando políticas de cooperación internacional y contribuyendo a la paz internacional ${ }^{116}$.

Por último, conviene aclarar lo que no es el califato ${ }^{117}$. No es una monarquía, dado que el califato no sería hereditario, aunque si vitalicio, se obtendría por elección de la umma y el califa ejercería realmente el poder ejecutivo. No es una república, ya sea presidencialista o parlamentaria, porque el califa no sería un jefe de Estado, ni un jefe de gobierno (los cuales comparten el poder ejecutivo con los ministros), ni el Consejo de la Umma sería un parlamento, sino que el califa detentaría todo el poder ejecutivo y legislativo (aunque tuviera asistentes delegados de cada área de gobierno) y el Consejo de la Umma funcionaría como un Consejo de Estado. No es un estado federal, en la medida en que el califato sería un sistema de gobierno unitario sin autonomía para sus provincias. No es un imperio, ya que ninguna región, ni ninguna raza, tendría más privilegios que otras, estando prohibidos por el Islam el nacionalismo y el racismo. No es una teocracia o un estado como el Vaticano, porque el califa no sería como un Papa, ya que sería, además del líder espiritual de los musulmanes, el gobernante de todas las tierras del Islam, ni sería infalible, ni designado por Alá, sino elegido por la umma. No es una tiranía o un estado totalitario, al ser el califa elegido por la umma y tener su mandato limitado por ley islámica, que prohíbe, entre otras cosas, la tortura, la incautación de la riqueza de los musulmanes o el encarcelamiento injustificado, estando, además, su capacidad legislativa sujeta a procedimientos igualmente recogidos en la sharía, que prevé, incluso, mecanismos de destitución del califa, en el caso en que éste se aparte de la misma. Y no es una democracia, en la medida en que la soberanía no residiría en el pueblo sino en Alá, que controlaría por medio de la sharía incluso el funcionamiento de la umma.

Así pues, al igual que el sistema económico islámico es una construcción teórica que ha de implantarse en la realidad, el califato moderno, como sistema político islámico, habría de ser igualmente instaurado para posibilitar el "renacimiento del Islam".

\footnotetext{
115 Athena Intelligence, op. cit., p. 13.

${ }^{116}$ El Ghazali, The Way of..., op. cit., pp. 368-372.

${ }^{117}$ Khilafah.com: "What is the Khilafah (Caliphate)?", Khilafah.com. Building a global movement for Khilafah, 20 February 2007, en http://www.khilafah.com/index.php/the-khilafah/issues/32-what-is-the-khilafah-caliphate.
} 


\section{CONCLUSIONES}

Llegados a este punto, creemos haber construido retrospectivamente una escuela islamista de la Economía Política del Desarrollo.

En primer lugar, hemos identificado una concepción islamista común del desarrollo, entendido como el renacimiento de la sociedad islámica recuperando el esplendor que tuvo durante la época califal, en la que religión y política no estuvieron separados.

Por otro lado, hemos identificado los principales autores de dicha escuela: Maududi, Qutb, Jomeini, Chapra, Siddiqi, Al Sadr, Al Zawahiri, El Ghazali....

Incluso, hemos identificado los principales vínculos de influencia intelectual existentes entre ellos: de Al Banna a Maududi, Qutb y El Ghazali; de Maududi a Qutb; de Maududi a Ahmad, Chapra y Siddiqi; de Maududi y Qutb a Al Zawahiri; de Jomeini a Al Sadr y a Jamenei...

Además, hemos identificado los principales centros de producción intelectual del pensamiento sobre el desarrollo: las sedes de la Hermandad Musulmana (Magreb, Oriente Medio...); las madrazas vinculadas con el Partido Islámico o Yamaat e Islami (Subcontinente Indio); la hawza de Nayaf (Irak); la Fundación Islámica (Reino Unido); el Centro de nvestigación de la Economía Islámica (Arabia Saudí); el Instituto de Investigación y Formación Islámica (Arabia Saudí); las universidades islámicas (repartidas por el Magreb, Oriente Medio y Asia); el gobierno iraní; las bases terroristas de Al Qaeda (Sudán, Afganistán, Pakistán, Irak...); las sedes del Partido de la Liberación o Hizb ut Tahrir (Oriente Medio, Magreb, Asia, Europa...)...

También, hemos identificado los principales textos de referencia: Jihad in Islam, Economic Problem of Man and its Islamic Solution, y The Islamic Law and Constitution, de Maududi; Social Justice in Islam, y Milestones, de Qutb; El gobierno islámico, de Jomeini; Our Economics, de Al Sadr; The Economic System of Islam, de Chapra; An Islamic Approach to Economic Development, de Siddiqi; "Declaration of War against the Americans Occupying the Land of the Two Holy Places", de Bin Laden; "Knights under the Prophet's Banner", de Al Zawahiri; The Way to the Revival of de Muslim Ummah, de El Ghazali...

Y por último, hemos identificado y sintetizado los principales tópicos: desarrollo y subdesarrollo (la decadencia, la dependencia, la reacción frente al colonialismo y el neocolonialismo y el renacimiento); bases económicas del desarrollo (el sistema económico islámico); y bases políticas del desarrollo (la yihad, el Estado islámico y el califato).

Así pues, existe una escuela islamista de la Economía Política del Desarrollo, que estaría formada por aquellos autores que se han acercado al estudio del desarrollo y el subdesarrollo de los países musulmanes partiendo de la premisa de que el Islam no es sólo una religión sino también es una forma de organización económica, social y política del Estado derivada del Corán, y que, por tanto, rechazan la separación entre la religión y el Estado; además dichos autores defienden el esfuerzo de interpretación individual del Corán. 
Por otro lado, esta escuela ha sido muy criticada, en especial por intelectuales occidentales entre los que destacan: Prior, Kuran, Roy, Kepel, Vick o Pipes ${ }^{118}$; nosotros no vamos a abundar en las críticas pues ello superaría los propósitos y dimensiones de este trabajo, aunque sí presentaremos una serie de valoraciones generales.

Con independencia del juicio moral y la condena que merece el uso de la violencia por parte de islamistas yihadistas, desde una perspectiva académica cabría hacer una serie de observaciones a los planteamientos de estos autores.

En primer lugar, no cabría su descalificación apriorística por basarse en una "verdad revelada"; a fin de cuentas el islamismo es una ideología tan válida como el neoliberalismo o el neomarxismo, y al igual que en estos casos también sobre ella procede elaborara una concepción del desarrollo.

Por otro lado, al basar todos sus argumentos no tanto en valores, sino en la interpretación más o menos literal de una serie de textos (el Corán y la suna), presenta serias dificultades para adaptar conceptos propios de la Edad Media a la era de la globalización.

Además, al existir la posibilidad de cada musulmán interprete libremente los textos islámicos se genera una gran ambigüedad en la manera de entender cómo generar el desarrollo en una sociedad islámica, de forma que lo que puede ser correcto para algunos musulmanes puede ser incorrecto para otros.

Tampoco debemos olvidar que el yihadismo islamista no puede ser entendido sólo como un comportamiento fanático religioso, sino que tiene sus raíces también en una interpretación del subdesarrollo de los países musulmanes y forma parte de una estrategia para alcanzar lo que ellos entienden como desarrollo.

Y por último, debe reconocerse que en los pocos países en los que se ha podido implementar de manera más o menos aproximada a los planteamientos teóricos un modelo de desarrollo basado en el establecimiento de un Estado islámico y en la reislamización de la sociedad, como serían Arabia Saudí, Irán o Afganistán (bajo el gobierno de los talibanes), éste no ha generado ese "renacimiento" esperado"

\footnotetext{
118 Véanse, por ejemplo: Prior; op. cit., Kuran, op. cit., Roy, op. cit.; Kepel, op. cit.; Vick; op cit.; o Pipes, Daniel: "Economía islámica - ¿qué significa?", La Razón, 1 October 2007, en http://es.danielpipes.org/article/4988.

${ }^{119}$ Aunque algunos islamistas argumentarían que en el caso de Arabia Saudí su gobierno sería en realidad un gobierno infiel, en el caso de Irán éste sufriría un cierto aislamiento por parte de Occidente y de los países musulmanes de orientación suní, y en el caso de Afganistán no hubo tiempo suficiente para que las reformas de los talibanes dieran sus frutos.
} 
No obstante, con todos sus defectos y sus virtudes, la concepción islamista del desarrollo viene existiendo casi desde mediados del siglo XX y, lo que es más importante, se ha desarrollado bastante en las dos últimas décadas, permitiéndonos hablar hoy día de la existencia de una escuela islamista de la Economía Política de Desarrollo ${ }^{120}$. Y esto es algo que los académicos occidentales no podemos seguir ignorando.

\footnotetext{
${ }^{120}$ En 1985 Samir Amín se preguntaba si existía una economía política del fundamentalismo islámico, no pretendíamos responder aquí a esa pregunta, pero si podemos afirmar que sí existe una economía política islamista del desarrollo.
} 